\title{
O Carnaval, a peste e a 'espanhola'*
}

\author{
Carnival, the plague, and the Spanish flu
}

Ricardo Augusto dos Santos

Pesquisador da Casa de Oswaldo Cruz,

Rua Doutor Satamini, 210 bloco B apto. 801

20270-231 Rio de Janeiro - RJ -

Brasil

raugusto@coc.fiocruz.br
SANTOS, R. A. DOS.: O Carnaval, a peste e a 'espanhola'. História, Ciências, Saúde - Manguinhos,

v. 13, n. 1, p. 129-58, jan.-mar. 2006.

Este texto apresenta algumas imagens (fotografias, pinturas) relativas às epidemias de Peste e Gripe Espanhola. Procuramos demonstrar como fenômenos históricos analisados comparativamente revelam semelhanças em distintas formações sociais. Apesar das diferenças de tempo e espaço, existem manifestações simbólicas coletivas invariáveis nas epidemias. Por exemplo, em várias ocorrências de peste, gripe ou cólera, a associação entre doença e castigo divino está presente. De forma análoga, indivíduos de comportamento "suspeito" foram e são apontados como propagadores das enfermidades, sejam pobres, judeus, irlandeses ou negros.

PALAVRAS CHAVES: História; Doenças; Rio de Janeiro; Representações Sociais.

SANTOS, R. A. DOS.: Carnival, the plague, and the Spanish flu História, Ciências, Saúde - Manguinhos,

v. 13, n. 1, p. 129-58, Jan.-Mar. 2006.

The article presents photographic and painted images related to epidemics of the plague and Spanish flu. Comparative analyses of this type of historical phenomena reveal similarities between diverse social formations. Despite differences in time and space, epidemics display certain invariable symbolic collective expressions. For example, disease and divine punishment have been linked during a number of plague, $\mathrm{flu}$, or cholera epidemics. Similarly, individuals whose behavior is 'suspicious' have been accused of spreading illness - for instance, the poor, Jews, Irish, or blacks.

KEYWORDS: history; disease; Rio de Janeiro; social representations. 
Assim é que é! Viva a folia!

Viva Momo - Viva a Troça!

Não há tristeza que possa

Suportar tanta alegria.

Quem não morreu da Espanhola,

Quem dela pode escapar

Não dá mais tratos à bola

Toca a rir, Toca a brincar...

Música de carnaval cantada nos Democráticos, promovendo um baile no dia 11 de janeiro de $1919 .{ }^{1}$

$\mathrm{O}$ trem avança pelos trilhos. Ao fundo, paisagens rurais. Apesar da brisa que refresca o rosto, está fazendo um calor! Também pudera, estamos em outubro e o Rio de Janeiro, nesta época, é bastante quente. Destino final de nossa viagem: a Festa da Penha. Originalmente uma festa religiosa e de raízes portuguesas, era realizada no alto do morro com orações. No entanto, no arraial do sopé da pedra onde está construída a igreja, o evento assumia um outro caráter. A ocasião atraía, segundo dados colhidos em jornais e revistas da época (1910-1920), cerca de 60 mil pessoas. A maioria vinha pelos trilhos da Leopoldina Railway. ${ }^{2}$

Os boêmios, o povo da lira, a gente do samba, e com eles os malandros, os valentes, os capoeiras sempre acorriam aos festejos da Penha. Misturavam-se às famílias (principalmente portuguesas) que lá iam para seus piqueniques regados ao farto verdasco. (Efegê, 1985, p. 75)

Esse encontro das camadas populares abria o período carnavalesco. As barracas montadas pelas tias baianas ofereciam comidas e bebidas. E havia cantoria! O samba lançado na Penha tinha seu sucesso garantido no carnaval seguinte, pois durante os finais de semana de outubro ele seria cantado nas rodas formadas. Um dos compositores que freqüentava a Festa da Penha era Oscar José Luiz de Morais (1883-1961), que entrou para a história da Música Popular Brasileira com o sugestivo nome de Caninha. ${ }^{3}$ Sua presença no cenário musical do Rio começou no início do século passado, quando ele começou a freqüentar as casas das tias baianas: Tia Dadá, na Pedra do Sal, e Tia Ciata, na Visconde de Itaúna, entre outras. Tendo composto algumas músicas que não obtiveram muita repercussão, Caninha compareceu à Penha, em outubro de 1918, com um maxixe que agradou. A partir daí, Caninha passou a freqüentar o evento ${ }^{4}$ e a compor sambas com relativo sucesso para os carnavais seguintes. A letra da sua música dizia assim:

A Espanhola está aí

A Espanhola está aí 
A coisa não está brincadeira

Quem tiver medo de morrer não venha

Mais à Penha

(Vasconcelos, 1985, p. 53)

Ditas estas palavras iniciais sobre o fato, no mínimo, curioso, tendo em vista a rapide $z^{5}$ com que a espanhola tornou-se tema de uma composição musical, interessam-nos algumas representações sociais das epidemias de peste e Gripe Espanhola. Se a gripe levou Caninha a escrever versos sobre a moléstia, outros homens igualmente tiveram suas vidas afetadas pelas enfermidades. Como responderam às doenças e à dor? Que explicações terão dado, frente a tantas mortes?

Este texto apresentará considerações sobre a semelhança das atitudes e dos símbolos das epidemias de peste e de Gripe Espanhola, esta no Brasil. Os processos de formação dos estados nacionais marcaram a criação das estruturas administrativas dos serviços públicos de saúde, levando cada país a organizações sanitárias diferentes sobre o controle das doenças. Porém, ao estudarmos essas epidemias, procuramos demonstrar como fenômenos históricos analisados comparativamente revelam semelhanças culturais em distintas formações sociais. ${ }^{6} \mathrm{~A}$ análise histórica enxerga similitudes em alguns acontecimentos relativos às enfermidades infectocontagiosas. ${ }^{7}$ Apesar das diferenças de tempo e espaço, não há como negar as manifestações simbólicas coletivas invariáveis nas epidemias. Por exemplo, em várias ocorrências de peste, gripe ou cólera, a associação entre doença e castigo divino está presente. De forma análoga, indivíduos de comportamento 'suspeito' foram e são apontados como propagadores do mal, sejam pobres, judeus, irlandeses ou negros. Mas, existe um elemento sempre constante: o medo. Uma presença avassaladora.

Durante as últimas décadas, as ciências sociais vêm se enriquecendo por meio do diálogo com outros campos e até produzindo novos setores de investigação a partir das relações com domínios epistemológicos diversos. É o caso da crescente influência das ciências do comportamento humano sobre o conhecimento das sociedades. Essas contribuições trazem à tona aspectos negligenciados por uma historiografia tradicional. É o caso das pesquisas recentes sobre o corpo, que destacam a evolução histórica e descontínua da capacidade humana de 'sentir odores'. ${ }^{8}$ Assim, influenciado pela interação com outras disciplinas, surge no campo acadêmico um leque de possibilidades para o estudo histórico, por exemplo, de conceitos como 'morte' e 'medo'. Qual será a historicidade desses elementos na cultura ocidental? Consideramos que uma investigação sobre as atitudes e os comportamentos surgidos com as epidemias poderá clarear essas zonas nebulosas. 
As imagens relacionadas às doenças geralmente expressam representações sociais semelhantes, ainda que em conjunturas históricas específicas. Analisando o cotidiano das epidemias, que comumente contém marcas trágicas, encontramos, em várias oportunidades, símbolos de outros flagelos humanos. Portanto, ainda ignoramos a repercussão dos temores ligados às epidemias sobre os comportamentos culturais. Mas, certamente, a história social das doenças contribuiu para trazer respostas a algumas indagações sobre os indivíduos e as formações sociais.

um irmão deixava o outro; o tio deixava o sobrinho, a irmã, a irmã; e, freqüentemente, a esposa abandonava o marido. Pais e mães sentiam-se enojados em visitar e prestar ajuda aos filhos... (Boccaccio, 1979, p. 14)

É de uma epidemia de peste que Giovanni Boccaccio (1313-1375) está falando. Embora seja uma obra literária, o Decameron ${ }^{9}$ detalha fatos sobre essa sombria doença, quando ela chegou a Florença, no ano de 1348. O medo inspirado pela moléstia resultou, como mostrou Boccaccio, em alteração dos comportamentos. O pânico foi total. A peste atacaria muitas vezes, inspirando outras obras ficcionais. ${ }^{10}$ Em Um diário do ano da peste, Daniel Defoe (1660-1731) descreve um surto que atingiu Londres em 1665:

o cadáver sempre ficava abandonado até os funcionários serem avisados e virem buscá-los ou até a noite, quando os carregadores dos carros dos mortos o recolheriam e o levariam embora. Aquelas criaturas sem medo que desempenhavam esta função não deixavam de revistar seus bolsos e algumas vezes retirar suas roupas... (Defoe, 2002, p. 96)

Está nos textos e na iconografia medieval, a presença da justiça divina imposta aos mortais como a razão para as epidemias. O flagelo era explicado como um castigo dos deuses contra os pecados cometidos pelos homens. É grande o número de imagens contendo seres celestiais arremessando lanças contra as pessoas. ${ }^{11}$ Igualmente, uma imagem muito presente na iconografia sobre a doença pestilenta é a "Dança Macabra" - a peste, representada por esqueletos humanos, arrastando todos para a morte. ${ }^{12}$ Após a Peste Negra, surgiram inúmeras imagens de cenas interativas entre vivos e mortos. As mais comuns, apresentando uma figura escura atemorizando as pessoas. A mensagem é imediata: a doença não distinguia estratificação social.

A pandemia que ficou conhecida como Peste Negra assolou a Europa durante o século XIV. Considerável parte da bibliografia sobre a Idade Média dedica poucas páginas aos fenômenos relacionados a esse terrível fato, que marcou profundamente o Ocidente, 
produzindo representações e símbolos que permanecem nos nossos dias. Segundo os cronistas, poucos acontecimentos foram trágicos como a doença que, por volta de 1347-1350, teria sido a causa do desaparecimento de um terço da população européia. O período entre 1300 e o século XVII ficou marcado pela introdução, na Europa, de moléstias oriundas da Ásia, provocada pelos movimentos populacionais e comerciais. A movimentação do agente da peste, Yersinia pestis, a partir dos nichos primitivos no sudoeste da China, transcorreu através das rotas das caravanas pela Ásia e espalhouse pelo continente a partir dos portos do Mediterrâneo. ${ }^{13}$

A história das epidemias, segundo William McNeill (1976), é marcada pelas rupturas epidemiológicas, que são rompimentos no equilíbrio dos seres vivos. Quando um agente infeccioso, como o da peste, mata seu hospedeiro, cria de certo modo uma situação limite, pois um novo organismo terá de ser encontrado para que a estabilidade ecológica entre parasita e hospedeiro continue existindo. Em linhas gerais, esse desajuste é um exemplo do que aconteceu, em grandes proporções, na Peste Negra, isto é, quando vários hospedeiros sendo eliminados passaram a procurar outros organismos: o bacilo, que estava na pulga, matava o rato. O hospedeiro seguinte passava a ser o homem. ${ }^{14}$

A peste é uma doença de animais transmissível ao homem e que afeta roedores, como o rato. As pulgas são vetores. É uma doença de considerável grau de mortalidade. Seu agente foi isolado em 1894. Ela se manifesta de três formas: a pneumônica, que ataca os pulmões; a septicêmica, que infecta a corrente sangüínea; e a bubônica, a mais comum, cujo nome deriva dos nódulos, que surgem nas axilas e virilhas dos doentes. De acordo com os narradores das epidemias de peste, os infectados sentiam fortes dores e, segundo os relatos literários e memorialísticos, morriam rapidamente após a manifestação dos primeiros sintomas. Os doentes tinham febre, cefaléia, tosse, suores e a presença incômoda dos bubões. O que saía de seu corpo, fosse hálito, sangue ou urina, cheirava mal.

A peste, como outras doenças, transformava o corpo, levando à representação simbólica de exclusão, estigma e imperiosa purificação do doente. Durante a Idade Média, regras eram adotadas com relação aos doentes de peste ou lepra, ou por aqueles identificados como portadores dessas enfermidades. Uma vez associada à moléstia ao doente, este era isolado. No caso da peste, símbolos eram associados aos odores. Talvez a imagem mais conhecida da iconografia da Peste seja a figura humana portando uma vara, usando uma máscara fechada, carregando um imenso bico no rosto. ${ }^{15}$ Dentro dessa máscara eram armazenadas ervas aromáticas. Os tratamentos mais comuns eram as sangrias, a cauterização dos bubões com ferro quente ou o corte com navalha e o uso de laxantes, arsênico e mercúrio. 
Para mim, isso encerra a questão e a calamidade se espalhou por contágio, ou seja, por certos vapores e fumos que os médicos chamam de eflúvios, pela respiração e pelo suor ou pelo mau cheiro das feridas dos doentes. Ou, quem sabe, também por outros meios, até mesmo acima do alcance dos próprios médicos, com eflúvios atingindo os sãos que chegassem a determinada distância de um doente e penetrando imediatamente nas partes vitais das pessoas ditas sadias, pondo seu sangue em imediata fermentação... (Defoe, 2002, p. 91)

Mas, diante do avanço do mal, a solução mais comum era a fuga. A doença asquerosa não devia mesmo inspirar solidariedade entre os homens. Talvez aumentasse o desejo de escapar do triste destino. Certamente, para muitos, o fim do mundo era próximo e certo, o que os levava a tentar esquecer a doença no prazer, como conta Boccaccio. ${ }^{16} \mathrm{O}$ contágio era extremamente rápido. A literatura narra casos de pessoas que dormiam com saúde e morriam antes de acordar. ${ }^{17}$ Nessas condições, o medo da morte produziria várias interpretações e algumas afirmariam uma desordem planetária (eclipses, cometas) ou a punição divina. Entre os possíveis responsáveis pela disseminação da peste, os judeus foram acusados e perseguidos. Como outras doenças que assolaram o mundo ao longo dos tempos, as epidemias de peste foram cercadas de várias explicações. Atribuía-se o mal ao ar contaminado, às posições desfavoráveis dos astros celestes ou à água envenenada em razão de um suposto ataque por parte dos judeus. Há, ainda, descrições de cavalheiros apocalípticos surgindo dos céus, atingindo os corpos com uma centelha e um fogo que queimava as pessoas e as cidades. ${ }^{18}$ Castigo divino, influência dos planetas e contaminação do ar e da água por 'suspeitos' eram respostas que davam sentido às epidemias e ao cotidiano massacrado pelo horror. ${ }^{19}$

quantos valorosos homens, quantas mulheres belíssimas, quantos galantes moços - que Galeno teria considerado mais do que sadios assim como Hipócrates, Esculápio e outros - tomaram o seu almoço de manhã com seus parentes, colegas, amigos, e, em seguida na tarde desse mesmo dia, jantaram no outro mundo, em companhia de seus antepassados! (Boccaccio, 1979, p. 17)

A devastação causada pela peste na Europa deixou seqüelas. $\mathrm{Na}$ arte, a representação da morte seria doravante mostrada sempre de forma medonha e assustadora, com a doença arrastando os mortos. Invariavelmente, a morte era simbolizada por um corpo humano armado de uma foice. $O$ conjunto de esqueletos representando a morte é presença obrigatória em qualquer inventário sobre a iconografia das epidemias. Mas, também, como destacamos, uma imagem muito constante são as figuras celestiais enviando lanças e flechas contra os homens pecadores. 
Muitos eram os que findavam seus dias na rua, de dia ou de noite. Inúmeros outros, mesmo morrendo em suas residências, levavam os seus vizinhos a não se manifestarem, mais por causa do mau cheiro dos próprios corpos em decomposição, do que por outro motivo... Tão grande era o número de mortos que, escasseando os caixões, os cadáveres eram postos em cima de simples tábuas. Não foi um só caixão a receber dois ou três mortos simultaneamente. Também não sucedeu uma vez apenas que esposa e marido, ou dois e três irmãos, ou pai e filho, foram encerrados no mesmo féretro. (Boccaccio, 1979, p. 16)

Não há dúvidas sobre o dramático impacto da Peste Negra. Muitos contemporâneos ficaram estarrecidos com a devastação causada pela doença. Há textos que afirmam que, em algumas cidades européias afetadas, mais da metade da população morreu. ${ }^{20}$ Mas, apesar da inevitável dor que sentiam (ou exatamente por causa dela!), observamos por meio das fontes que naquele período aconteceu uma busca aos prazeres, antes que o mundo acabasse. Ocorreu uma alteração dos comportamentos. Alguns autores afirmam que se iniciou na época um interesse pela arte trágica, representando a ruptura dos costumes sociais. ${ }^{21}$

entregar-se francamente à bebida como aos prazeres, dar a volta à cidade divertindo-se, e uma canção nos lábios, conceder toda satisfação possível às suas paixões, rir e gracejar dos mais tristes acontecimentos, tal era segundo suas próprias palavras o remédio mais seguro contra um mal tão atroz. Para melhor passar de tal princípio à prática, iam dia e noite de taberna em taberna, bebendo sem constrangimento nem medida. (Delumeau, 1990, p. 127)

Entre os episódios históricos de medo coletivo, como guerras e escassez de alimentos, destacam-se os períodos epidêmicos. Doença sempre presente, a peste criou nas populações entre as quais aconteceram seus violentos surtos um estado de pânico. ${ }^{22}$ Delumeau (1990), em estudo sobre o medo no mundo ocidental, analisou as cidades acometidas por peste destacando a perda dos laços comunitários durante as epidemias. As populações tinham seus hábitos modificados pelos acontecimentos. Vários contemporâneos que viveram tais experiências ressaltam a 'fuga da realidade' e a permissividade dos costumes. Defoe (2002) descreve multidões abandonando Londres. ${ }^{23}$

Um número considerável de pesquisadores tem procurado estudar as atitudes e os comportamentos humanos perante o medo e as doenças. ${ }^{24}$ O historiador Philippe Ariès (1989) demonstra que até o século XIX predominou no Ocidente a aceitação da morte como elemento indissociável da vida. Os atos referentes à morte reforçavam a solidariedade entre as pessoas. Porém, quando a morte 
acontece em períodos de graves crises sociais como guerras, fome e epidemias, torna-se um elemento perturbador à sociedade. Diante da 'indesejada' desaparecem os ritos, as atitudes sociais modificamse, levando à instabilidade das normas. As visões do apocalipse integram-se no imaginário social, instalando nas cidades o medo às epidemias, colaborando na desagregação social.

Inúmeras imagens reforçam o simbolismo da doença. Como dissemos, várias pinturas exibem ataques de deuses irados, arremessando setas de fogo contra as comunidades. O que se acentua é o aspecto da punição. São imagens de lanças vindas dos céus ou de um ser divino, em direção a um grupo ou cidade. Este é um dado relevante nas representações. A mensagem transmite a idéia de que a doença atacava a todos. ${ }^{25}$ Sem distinção. Eliminando indiferentemente todo mundo. A imagem da 'dança macabra' arrastando todos os homens representa muito bem essa idéia. Da mesma manei$\mathrm{ra}$, a iconografia não deixou de 'caricaturar' o aspecto súbito da morte por peste, representada pelo esqueleto ou por uma figura escura e medonha armada com uma foice. Essa representação seria muito utilizada em campanhas de políticas públicas de saúde no Brasil, ratificando no tempo contemporâneo o conceito de morte de séculos passados.

No início da epidemia de gripe no Rio de Janeiro, em setembro de 1918, os habitantes começaram a apresentar febre e a caírem doentes. Era a 'Espanhola', a doença que vinha da Europa pelos navios que ancoravam nos portos brasileiros. Numa cidade com cerca de um milhão de habitantes, morreram, segundo estimativas, 15 mil pessoas. E 600 mil teriam ficado enfermas. Os médicos não sabiam como tratar o mal e receitaram quinino, caldo de galinha e limão. Não que o Brasil não estivesse avisado. A gripe estava dizimando na Europa e mataria, de acordo com as estatísticas mais modestas, de vinte a trinta milhões de pessoas em todo o mundo. E não existem registros ou conhecimento de quantos teriam morrido no Oriente - na China, por exemplo.

Morrer na cama era um privilégio abusivo e aristocrático. $\mathrm{O}$ sujeito morria nos lugares mais impróprios, insuspeitados: - na varanda, na janela, na calçada, na esquina, no botequim... Muitos caíam, rente ao meio-fio, com a cara enfiada no ralo. E ficavam, lá, estendidos, não como mortos, mas como bêbados. Ninguém os chorava, ninguém. Nem um vira-latas vinha lambê-los. Era como se o cadáver não tivesse nem mãe, nem pai, nem amigo, nem vizinho e, nem ao menos, inimigo. (Rodrigues, 1967, p. 72)

Os cariocas morriam em casa, na rua, no trabalho, em qualquer lugar, e iam sendo recolhidos pelos funcionários da Prefeitura. Estes jogavam os corpos nas carroças do serviço de limpeza pública. Os cadáveres eram empilhados. Conta-se que quando descobriam 
alguém dado como morto e ainda vivo, acabavam de matá-lo com as pás. Nos cemitérios, coveiros abriram valas, onde eram despejadas dezenas de mortos. E, quanto mais corpos acumulados, mais a situação piorava. Naquele momento, era impossível ignorar a morte. Sua presença era totalmente ameaçadora. Dessa maneira, a Gripe Espanhola impossibilitou os rituais que acompanhavam a morte, ainda bastante comuns na cidade. ${ }^{26} \mathrm{O}$ luto, o velório e o enterro, que sucedem ao falecimento, além de comporem a solidariedade entre as pessoas, eram, para as comunidades, uma maneira de assegurar uma passagem tranqüila para a vida eterna. ${ }^{27}$

Frente ao desconhecimento ou ineficácia das medidas terapêuticas que pudessem impedir o contágio ou curar os doentes, as autoridades públicas restringiram-se a orientar a população a evitar os lugares de aglomeração. Nesse momento, a cidade transformou-se num caos generalizado. Falta de alimentos e saques aos armazéns. Para completar este quadro tenebroso: o problema dos cadáveres insepultos. Não havendo pessoal suficiente para recolher e enterrar os mortos, foram utilizados os presidiários. Mesmo assim, o cenário de corpos amontoados pelos cemitérios ou abandonados pelas ruas desertas era desolador. O pânico instalado com a epidemia de gripe está presente nos relatos. Diante da inoperância dos responsáveis pela saúde pública em relação à epidemia e ao desespero da população, começaram a surgir manifestações religiosas (procissões) pedindo ajuda a São Sebastião. ${ }^{28}$

Com o desenrolar dos fatos, as transformações deteriorando a vida urbana, atormentando os habitantes, aumentava ainda mais o temor coletivo. No período mais crítico, a população ficou desesperada. A divulgação pela imprensa do número de óbitos, da falta de assistência médica e das atrocidades cometidas durante a epidemia intensificava o clima de medo. Além disso, em época de epidemia, o não cumprimento dos rituais fúnebres aumenta o temor em relação aos mortos. São inúmeras as referências aos cadáveres insepultos. A todo esse cenário podemos acrescentar o ar fétido, emanado das covas, casas e ruas, onde os corpos permaneciam à espera de sepultamento. ${ }^{29}$ Outro aspecto que deve ser considerado diz respeito às atitudes desencadeadas a partir do terror instalado com a gripe. Alucinações coletivas, derivadas do contexto epidêmico. As narrativas mais terríveis falam de atos insensatos cometidos por pessoas transtornadas com a situação. O medo apossou-se pouco a pouco da população.

A interrupção das atividades econômicas e tantas outras adversidades inerentes aos surtos epidêmicos não foram evitadas e nem houve planejamento para aplacar os efeitos da espanhola. ${ }^{30} \mathrm{~A}$ doença inicialmente apresentou-se aos habitantes do país como um mal terrível, porém muito distante. As autoridades não tomaram medidas para controlar a gripe ou ao menos atender a população doente. 
Segundo Teixeira (1993), tanto a imprensa quanto os responsáveis pelos serviços de saúde pública punham em dúvida a existência da espanhola no Brasil. Os casos observados poderiam ser outras moléstias ainda não diagnosticadas. Para além da discussão científica, um fator deve ser observado: a aceitação de que a epidemia havia invadido o país evidenciaria a fragilidade das políticas de saúde do Estado brasileiro.

Apresentando-se como uma doença aguda, geralmente benigna, a gripe pode transformar-se, por mutações do vírus, em uma enfermidade fatal. Transmitida por contágio direto, tem como sintomas principais febre, prostração e dores musculares. Embora ainda seja veiculada a idéia do caráter 'democrático' dessa doença (e de outras também), que parece atingir de forma indiferenciada as classes sociais, as observações das epidemias a partir do final do século XIX mostram que na verdade sua atuação é muito mais letal em organismos debilitados por condições de sobrevivência precárias.

Porque lá se morria, a toda a hora. Mas eis o que eu queria dizer: vinha o caminhão de limpeza pública, e ia recolhendo e empilhando os defuntos. Mas nem só os mortos eram assim apanhados no caminho. Muitos ainda viviam. Mas nem família, nem coveiros, ninguém tinha paciência. Ia alguém para o portão gritar para a carroça de lixo: - Aqui tem um! Aqui tem um! E, então, a carroça, ou o caminhão, parava. O cadáver era atirado em cima dos outros. Ninguém chorando ninguém. (Rodrigues, 1967, p. 73)

Embora os políticos e administradores do Rio de Janeiro não acreditassem, ou não quisessem aceitar, a epidemia foi dominando a cidade. Em outubro, a imprensa noticiou a existência de doentes em locais de grande aglomeração: quartéis, fábricas e escolas. Por volta da segunda semana era enorme a quantidade de casos fatais da doença. Nesse momento, o número de pessoas atingidas havia crescido, deixando a população apavorada. A violência da gripe transformava a cidade, paralisando vários setores das atividades urbanas. Frente à inércia dos governantes em relação à epidemia e ao desespero da população, restava aos habitantes organizar manifestações religiosas implorando a São Sebastião que cuidasse da peste que ameaçava a cidade. ${ }^{31}$ Desde os tempos medievais esse santo era considerado defensor das comunidades frente aos perigos epidêmicos, além de ser o padroeiro da cidade.

No final de outubro, a situação era alarmante. Milhares de enfermos apareciam sem cessar. A epidemia forçara o fechamento do comércio e das indústrias, bem como a interrupção dos serviços públicos. A cidade estava paralisada. Frente ao desconhecimento de medidas que pudessem impedir o contágio ou tratar os doentes, o governo passou a distribuir quinino - contudo, sem saber o real valor terapêutico dessa substância no combate à gripe ou o perigo 
da sua ingestão sem controle. Surgiam na imprensa receitas as mais peculiares, que prometiam curar a doença. Além disso, os produtos (galinhas, quinino, ovos e limão), supostamente tidos como eficazes, foram alvo de intensa especulação comercial.

Verdadeiros ou falsos os boatos era como se fossem realidade pelo impacto emocional que causavam. Descrevia-se a fome. Os ataques às padarias, armazéns e bodegas por aglomerados de esfaimados e convalescentes esquálidos, roubando e tossindo. Dizia-se de famílias inteiras desamparadas ... uns com febre outros com fome; de criança varada, sugando o seio da mãe morta e podre... (Nava, 1976, p. 202)

A desorganização das atividades comerciais provocou uma grave crise de abastecimento. Se nas áreas próximas do centro urbano havia dificuldade em conseguir alimentos, nas áreas suburbanas eles eram extremamente escassos. Para amenizar a situação, o governo passou a distribuir caldo de galinha e pão para a população. Entretanto, noticiadas pela imprensa, as reclamações de moradores dos subúrbios ${ }^{32}$ deixam claro que essa medida foi inoperante. $\mathrm{Na}$ impossibilidade de conseguir alimentos, passou a ser comum o saque aos armazéns e depósitos de comida. De forma semelhante, a ausência de assistência médica nas regiões mais distantes aumentou o número de mortes nessas áreas.

Era apavorante a rapidez com que ela ia da invasão ao apogeu, em poucas horas, levando a vítima às sufocações, às diarréias, às dores lancinantes, ao letargo, ao coma, à uremia, à síncope e à morte em algumas horas ou poucos dias. Aterravam a velocidade do contágio e o número de pessoas que estavam sendo acometidas. Nenhuma de nossas calamidades chegara aos pés da moléstia reinante: o terrível não era o número de casualidades mas não haver quem fabricasse caixões, quem os levasse ao cemitério, quem abrisse covas e enterrasse os mortos. O espantoso já não era a quantidade de doentes, mas o fato de estarem quase todos doentes, a impossibilidade de ajudar, tratar, transportar comida, vender gêneros, aviar receitas, exercer, em suma, os misteres indispensáveis à vida coletiva... (Nava, 1976, p. 201)

E, em novembro, assim como surgira, a 'Espanhola' foi embora. Cautelosas, as pessoas começaram a sair de casa e retornaram ao cotidiano. A partir desse momento, desencadeou-se um conjunto de atitudes e sentimentos da população em relação à epidemia, marcados pelo contexto de medo e alegria. Pesquisando em jornais os dados sobre a gripe que matou milhares de pessoas, encontramos inúmeras músicas (ver anexo) 'brincando' com os fatos da dolorosa epidemia, além de várias notas sobre a criação de blocos carnavalescos e convites para bailes fazendo alusão à gripe. Parece 
que os cariocas não se intimidaram e caíram na farra. ${ }^{33}$ Os jornais documentam a alegria incomum ${ }^{34}$ que tomou conta da cidade. Os memorialistas qualificam o Carnaval de 1919 como um dos mais animados que o Rio de Janeiro teve: bailes, batalhas de confete e incontáveis blocos espalhados pelos bairros. Ao que parece, houve uma dramatização carnavalesca da situação que os vitimara. Tudo era motivo de alegria e riso. ${ }^{35} \mathrm{~A}$ 'Espanhola' atacara também outras cidades, mas o Rio de Janeiro conheceu este fenômeno interessante: o Carnaval de 1919, o primeiro depois da gripe. As revistas ilustradas como O malho, Careta e outras documentam em dezenas de fotografias a folia que animou a cidade. Vários acontecimentos semelhantes envolvendo o carnaval e/ou as epidemias aconteceram, mas carecem de pesquisas mais acuradas. Como, por exemplo, a epidemia de febre amarela no Rio de Janeiro em 1849-1850, o "Carnaval de inverno" de 1892, marcado para as datas de 26, 27 e 28 de junho por receio das epidemias que acometiam a cidade no verão, e o acontecimento da morte do barão do Rio Branco. Às vésperas do Carnaval de 1912, morreu o barão, ministro das Relações Exteriores. Para homenageá-lo, o governo determinou que o Carnaval fosse adiado para abril. Não adiantou. O povo brincou os dois carnavais, cantando a seguinte marchinha: "Com a morte do Barão/ tivemos dois carnavá/ Ai que bom, ai que gostoso/ Se morresse o Marechá". O 'Marechá', no caso, era o presidente, marechal Hermes da Fonseca.

começou o Carnaval e, de repente, da noite para o dia, usos, costumes e pudores tornaram-se antigos, obsoletos, espectrais. As pessoas usavam a mesma cara, o mesmo feitio de nariz, o mesmo chapéu, a mesma bengala (naquele tempo, ainda se lavava a honra a bengaladas). Mas algo mudara. Sim, toda a nossa íntima estrutura fora tocada, alterada e, eu diria mesmo, substituída... Éramos outros seres que nem bem conheciam as próprias potencialidades. Cabe então a pergunta: e por quê? Eu diria que era a morte, sim a morte que desfigurava a cidade e a tornava irreconhecível. A Espanhola trouxera no ventre costumes jamais sonhados. E, então, o sujeito passou a fazer coisas, a pensar coisas, a sentir coisas inéditas e, mesmo, demoníacas... Estou aqui reunindo as minhas lembranças. Aquele Carnaval foi, também, e sobretudo, uma vingança dos mortos mal vestidos, mal chorados e, por fim, mal enterrados. Ora, um defunto que não teve o seu bom terno, a sua boa camisa, a sua boa gravata é mais cruel e mais ressentido do que um Nero ultrajado. E o Zé de S. Januário está me dizendo que enterrou sujeitos em ceroulas, e outros nus como santos. A morte vingou-se, repito, no Carnaval... E tudo explodiu no sábado de Carnaval. Vejam bem: até sexta-feira, isto aqui era o Rio de Machado de Assis; e, na manhã seguinte, virou o Rio de Benjamin Costallat ou, ainda, do Theo Filho... Desde as primeiras horas de sábado, houve uma obscenidade súbita, nunca vista, e 
que contaminou toda a cidade. Eram os mortos da Espanhola e tão humilhados e tão ofendidos que cavalgavam os telhados, os muros, as famílias... Nada mais arcaico do que o pudor da véspera. Mocinhas, rapazes, senhoras, velhos cantavam uma modinha tremenda. Eis alguns versos: “Na minha casa não racha lenha. $\mathrm{Na}$ minha racha, na minha racha/ Na minha casa não há falta de água/ Na minha abunda", etc. etc. As pessoas se esganiçavam nos quatro dias... (Rodrigues, 1967, p. 76)

Ao compararmos as epidemias, encontramos semelhanças nos relatos sobre a ocorrência de peste na Europa e da Gripe Espanhola no Brasil em 1918. A mesma perda dos laços comunitários, a ruptura das normas sociais, a fuga, o medo e a surpreendente alegria. Durante a Peste Negra, de acordo com os relatos, aconteceu a busca desenfreada pelo prazer. No Rio de Janeiro, no Carnaval de 1919, tivemos uma festa, onde antes havia medo e morte. Segundo a descrição dos sobreviventes e vítimas da peste e da gripe, o medo e a presença avassaladora da morte levavam à alteração das normas sociais durante as epidemias - até mesmo expondo-se as pessoas aos perigos de um contágio. No entanto, o prazer marcava os momentos que poderiam ser os últimos da vida.

Para o escritor Carlos Heitor Cony, um dos fatos que demonstram a rápida mudança dos padrões de relacionamento social durante o Carnaval de 1919 deve-se ao acontecimento, citado por ele, de que foram cometidos inúmeros 'defloramentos' durante o período carnavalesco. ${ }^{36}$ Segundo Cony, cerca de 2 mil casos, somente nas localidades próximas da Rua Santo Amaro (Catete e Glória). Tantos que, os que ocasionaram gravidez, provocaram o surgimento da expressão "os filhos da gripe". Porém, neste texto, não analisamos tais fatos. Estamos pesquisando os documentos policiais do período, seguindo os conselhos do historiador Sidney Chalhoub, quando trabalhou processos criminais: ${ }^{37}$

O fundamental em cada história abordada não é descobrir o que realmente se passou - apesar de isto ser possível em alguma medida -, e sim tentar compreender como se produzem e se explicam as diferentes versões que os diversos agentes sociais envolvidos apresentam para cada caso. As diferentes versões produzidas são vistas neste contexto como símbolos e interpretações cujos significados cabe desvendar. Estes significados devem ser buscados nas relações que se repetem sistematicamente entre as várias versões, pois as verdades do historiador são estas relações sistematicamente repetidas. (Chalhoub apud Esteves, 1989, p. 129)

Nos textos dos memorialistas, algumas características ficam ressaltadas. Por exemplo, o medo da morte, este sentimento presente nas sociedades ocidentais, principalmente quando associado às 
guerras, fomes e epidemias. Segundo a descrição das narrativas, o medo da gripe e o falecimento de parentes, amigos e vizinhos levavam a um 'relaxamento' das normas sociais durante e após o período epidêmico. ${ }^{38} \mathrm{O}$ escritor Nelson Rodrigues (1912-1980) apresenta em suas memórias a lembrança da Gripe Espanhola no Rio, descrevendo a banalidade da morte durante o período. ${ }^{39}$ A epidemia impossibilitou que os rituais e o funeral fossem executados. Já dissemos que a obediência dessas práticas religiosas reforçava a solidariedade social. Impossibilitados de seguir as regras dos sepultamentos, os vivos tinham aumentado o temor da morte. Alguns mortos permaneciam insepultos, e cadáveres eram trocados uns pelos outros. Entre inúmeras descrições assustadoras de atos de crueldade e perversão, contam-se casos de homicídio, suicídio e agressão sexual, quase sempre de maneira trágica.

Mas, encontramos também vestígios de alegria. Assim, a festa e o prazer marcavam os momentos de subversão da ordem que poderiam ser os últimos atos da vida. $\mathrm{O}$ advento da gripe modificou, rapidamente, as atitudes diante da morte. No entanto, consideramos esse período de 'anormalidade' como intrinsecamente relacionado ao contexto temporal e espacial da cidade do Rio de Janeiro. Certamente, a população carioca foi construtora das novas ordens sociais. Porém, em nossa análise, argumentamos que as condições e os modos de vida, além de posicionamentos específicos de classe, condicionaram as 'respostas' que os indivíduos formulavam. Sueann Caulfield (2000), em importante texto, demonstra que os 'defloramentos' eram, no mesmo período da gripe, numerosos. ${ }^{40} \mathrm{~A}$ epidemia transformou o cotidiano das pessoas. Sim, isto é evidente. Contudo, devemos reconhecer que as mudanças ocorridas deramse em meio às estruturas sociais e culturais existentes na cidade naquela conjuntura.

Bem ou mal, como era possível, frescos ou já decompostos, quando os pobres mortos chegavam aos cemitérios não havia gente suficiente para enterrá-los. Era muito defunto para os poucos coveiros do trivial - assim mesmo desfalcados pela doença. Foram contratados amadores a preços vantajosos. Depois vieram os detentos. Espalharam-se então horrores. Descreviam-se os criminosos cortando dedos aos cadáveres, rasgando-lhes as orelhas para roubar os brincos, os anéis, as medalhas e os cordões que tinham sido esquecidos. Às moças mortas, arrancavam as capelas e levantavam as mortalhas para ver as partes. Que curravam as mais frescas antes de enterrá-las. Melhores as que estavam ficando moles: eram tiradas dos caixões e comidas de beira-de-cova... (Rodrigues, 1967, p. 77)

A Peste Negra foi assim chamada porque os mortos ficavam pretos e sangravam. Em covas abertas os corpos fedorentos eram en- 
* $\mathrm{O}$ autor agradece a contribuição de Luiz Antonio Teixeira e de Leonardo Arruda Gonçalves. As reproduções fotográficas foram realizadas por Roberto Jesus Oscar e Vinicius Pequeno. terrados. Quantos? 25 milhões? Quem era culpado? Judeus foram responsabilizados porque supostamente estariam envenenando a água. Teria sido assim tudo tão horrível? As avaliações dos que viveram os vários surtos epidêmicos das doenças são exageradas. Todavia, houve sim, muito do que as crônicas descrevem. Embora os textos de Boccaccio, Nelson Rodrigues, Pedro Nava (1903-1984) e D. Defoe sejam repletos de imaginação e os depoimentos dos que viviam nas cidades - vestígios que escaparam à destruição - estejam impregnados de dor e sentimento, como negar as testemunhas dos fatos? Não obstante, esses relatos embaçados pelo tempo trazem à tona discursos de um quadro certamente muito penoso. Mas, sem dúvida, devemos manter uma aguçada crítica ao trabalhar tais fontes. $^{41}$

\section{[ANEXO]}

Trechos de músicas cantadas no carnaval de 1919. O correio da manhã, fev. 1919. São inúmeras as referências ao chamado Chá da Meia-Noite e à Santa Casa da Misericórdia, até mesmo com nomes de "Blocos" satirizando o chá e a Santa Casa. Existia o boato de que a Santa Casa distribuía um chá aos doentes, e que nesse chá havia um veneno.

Musica do Bloco "Miséria e Corda":

"Miséria e Corda é o nome

Deste bloco afamado

Onde a desgraça e a fome

me poz assim aleijado.

Meia-Noite vai bater

Olho vivo,

Um passo a frente

Vão beber

E este Chá que mata a gente

Gregorio, Gaspar e Gouveia

todos tres sofrem da bola

tiveram uma vez a idéia

de lutar com a espanhola

meia-noite vai bater

minha sogra está doente

vou interná-la num hospital

dando-lhe o chá bem quente

fico livre deste animal.

vou-me embora desta terra 


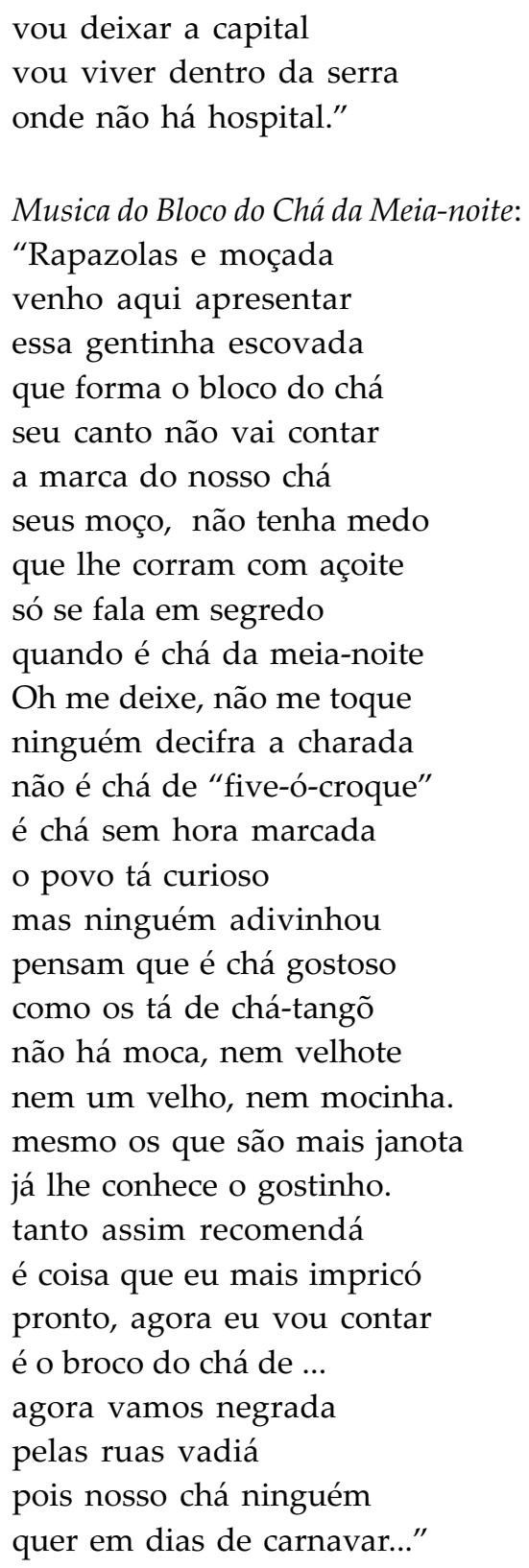




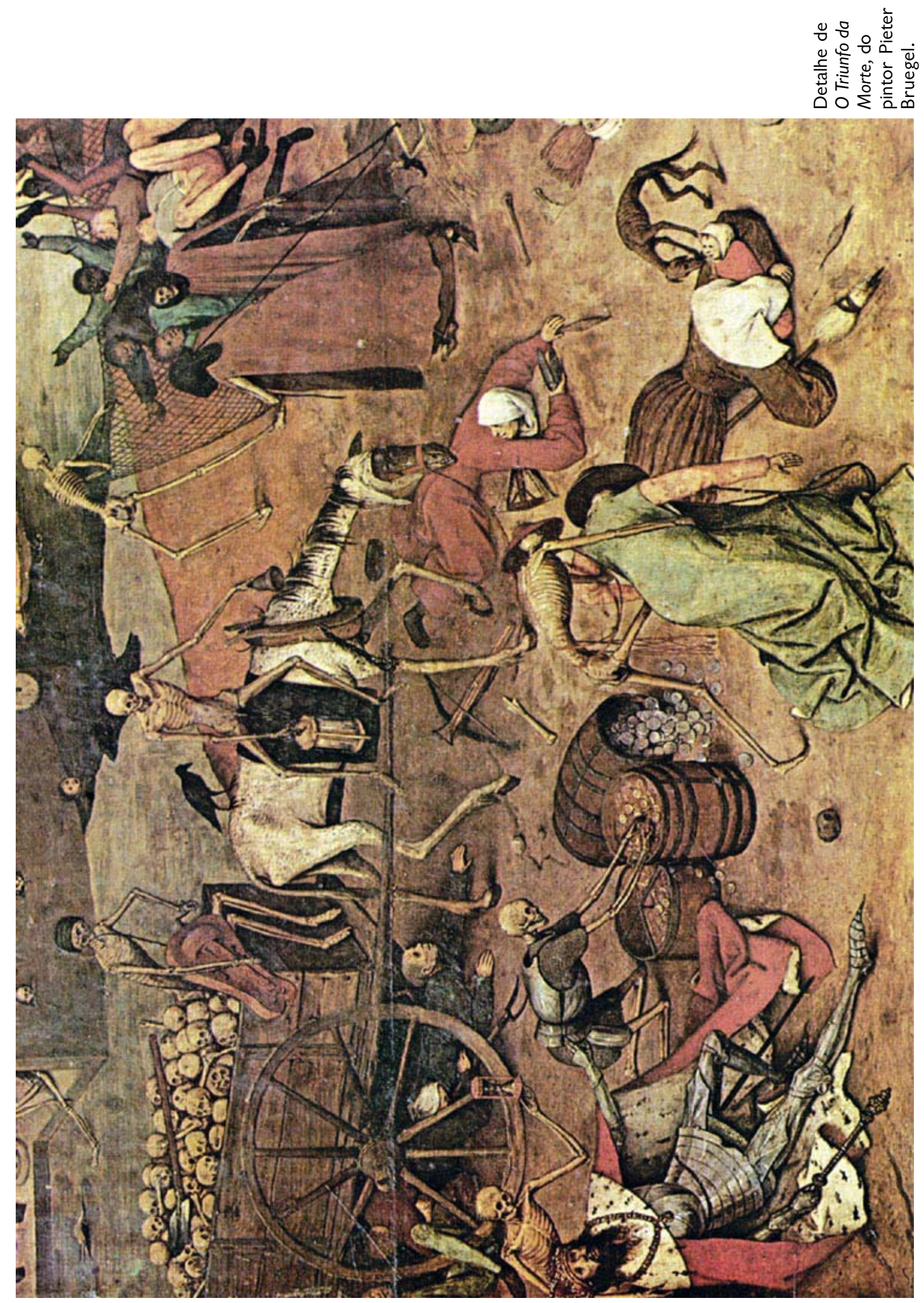




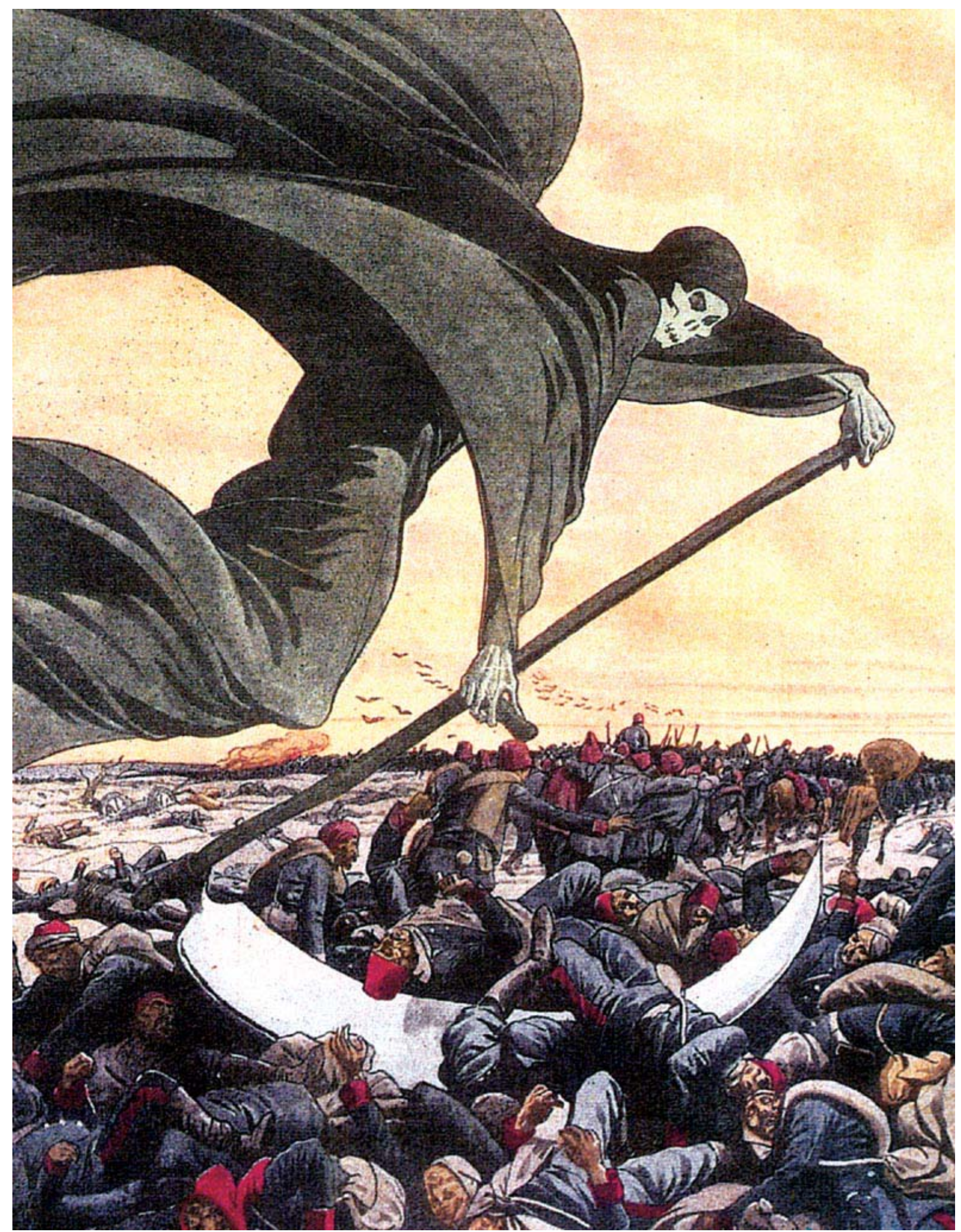

A Morte. In: Bruno Latour, Pasteur, une science, un style, un siècle. Paris: Librairie académique Perrin, 1994, p. 30. 


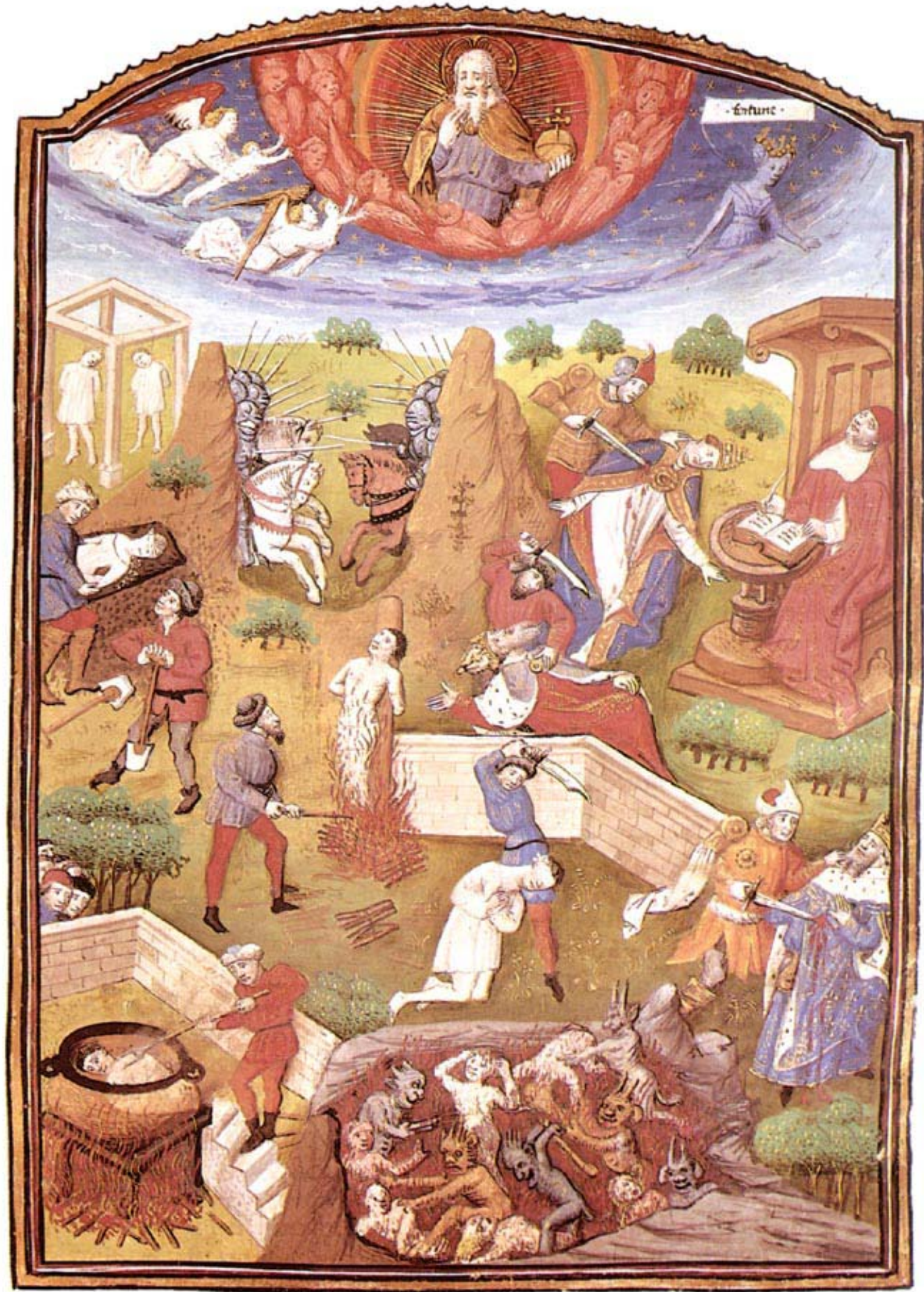

Purificação. In: Georges Duby, Ano 1000, ano 2000: na pista de nossos medos. São Paulo: Unesp, 1999. 

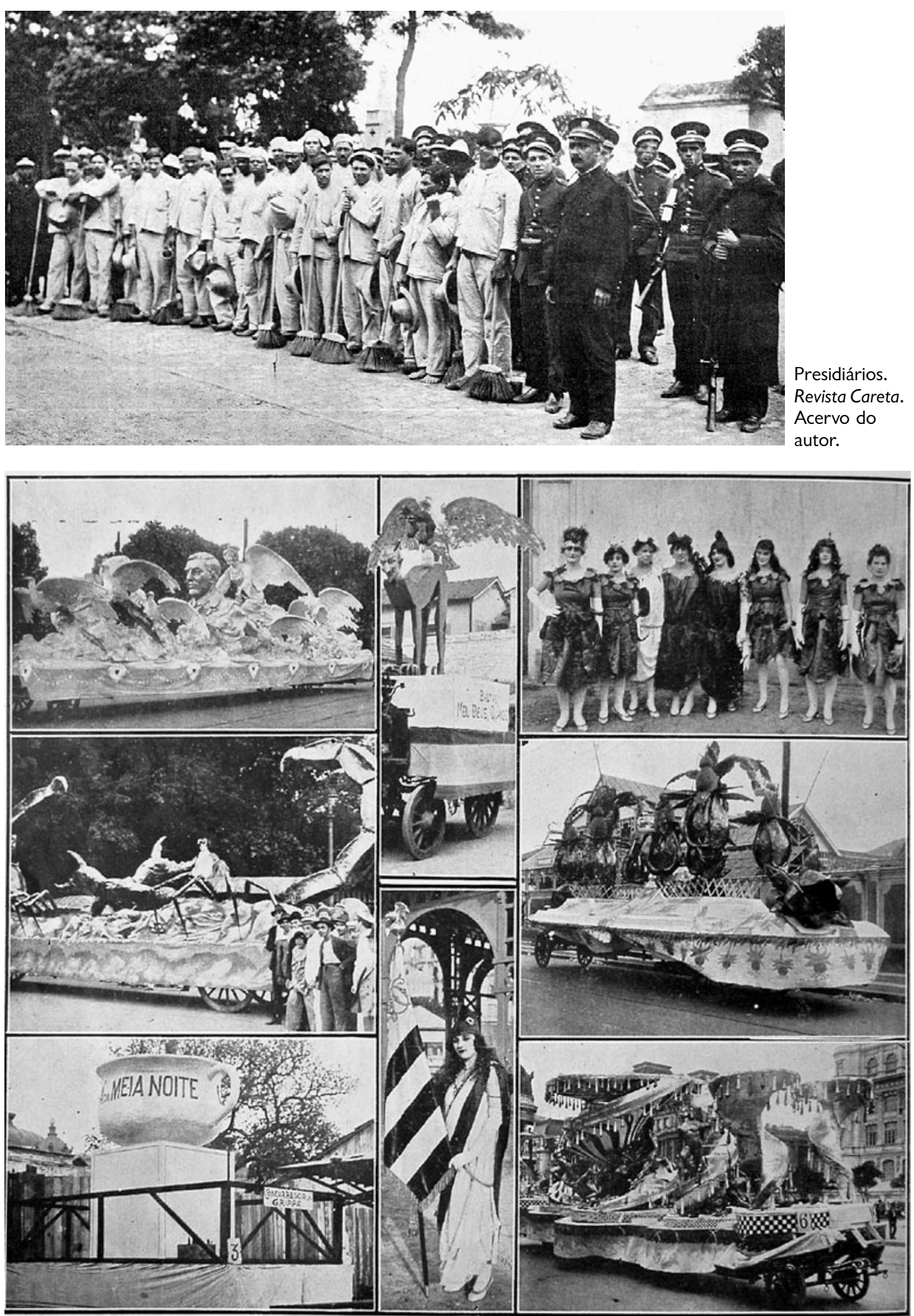

Foto de carro dos Democráticos. Revista Careta. Acervo da Biblioteca Nacional, Rio de Janeiro. 


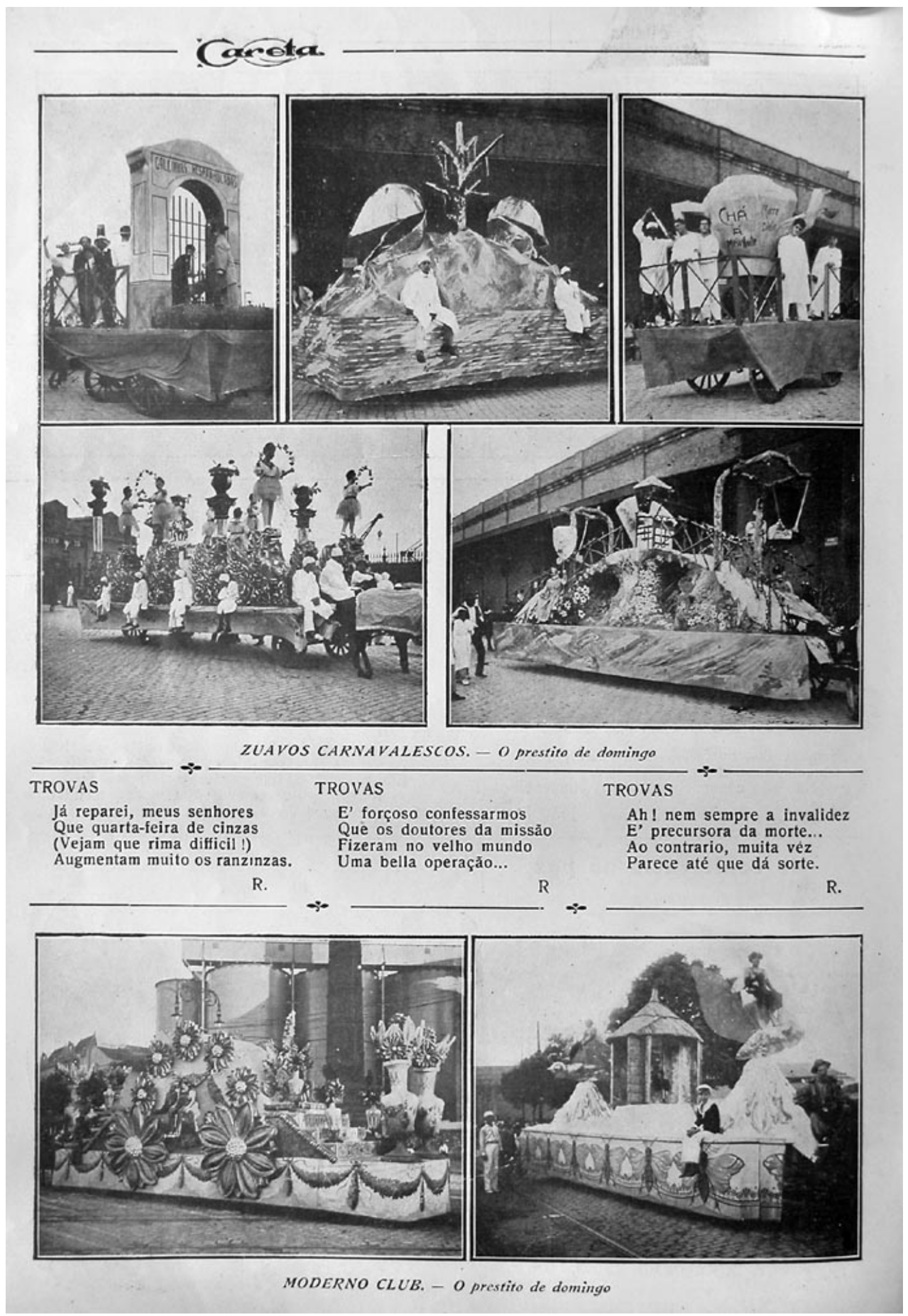

Os elementos presentes na epidemia foram alvo de crítica ou brincadeira. Nesta imagem encontramos alusões ao suposto chá da meia-noite e ao poder terapêutico das galinhas. Revista Careta. Acervo da Biblioteca Nacional. 

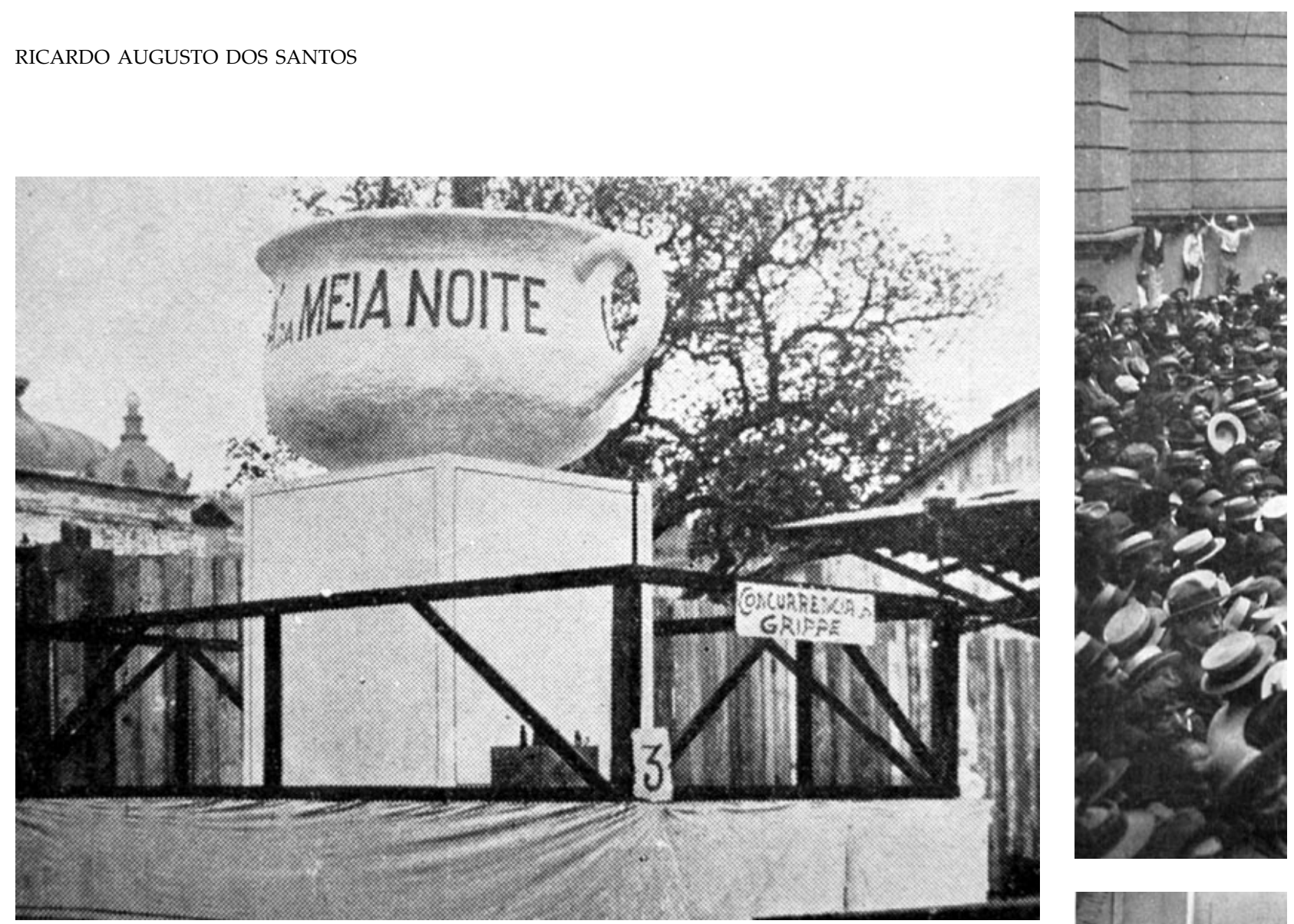

Foto de detalhe do Carro dos Democráticos. Revista Careta. Acervo da Biblioteca Nacional. São inúmeras as referências satirizando o boato de que a Santa Casa distribuía um chá contendo veneno aos doentes de Gripe Espanhola.

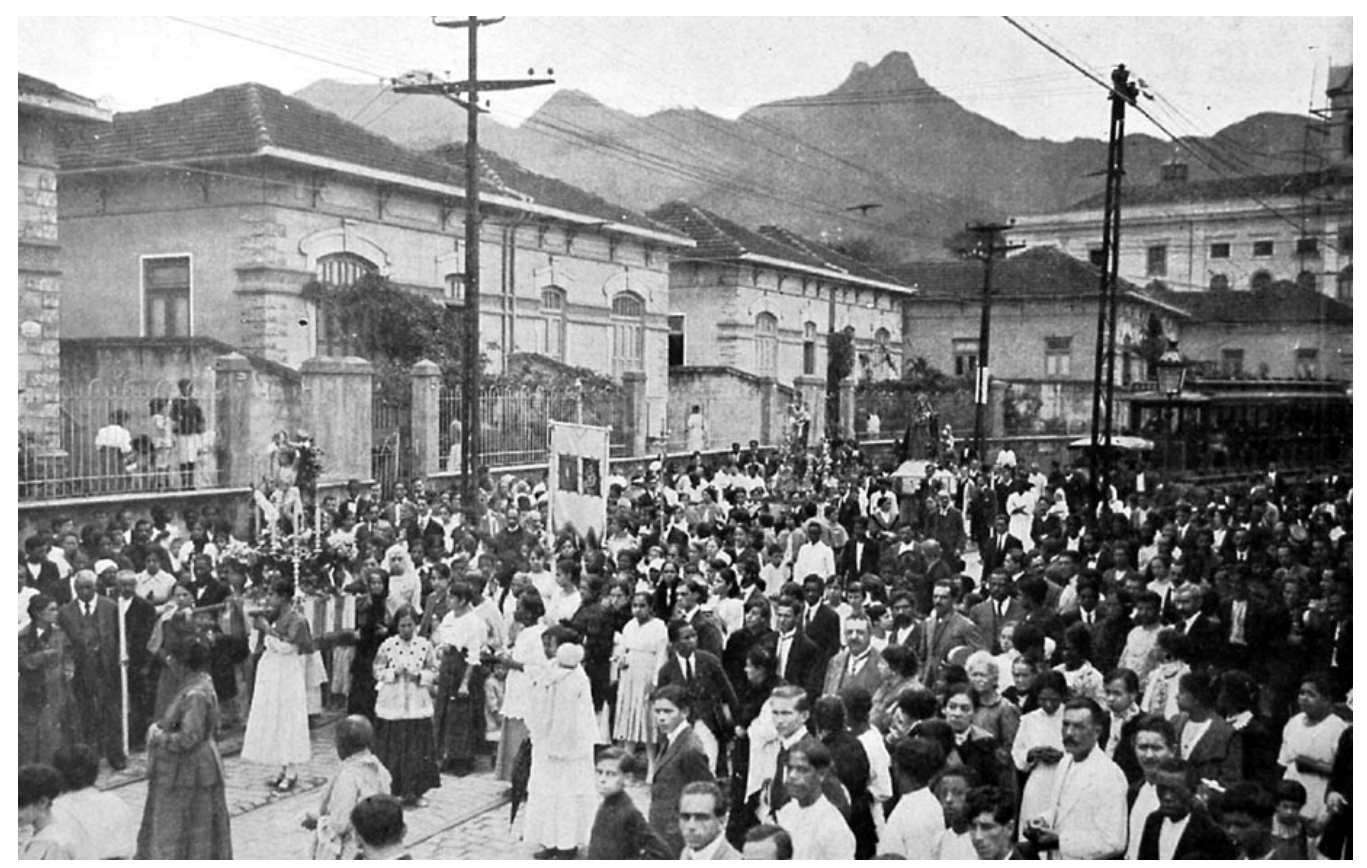

Procissão. Revista Careta. Acervo Casa de Rui Barbosa.

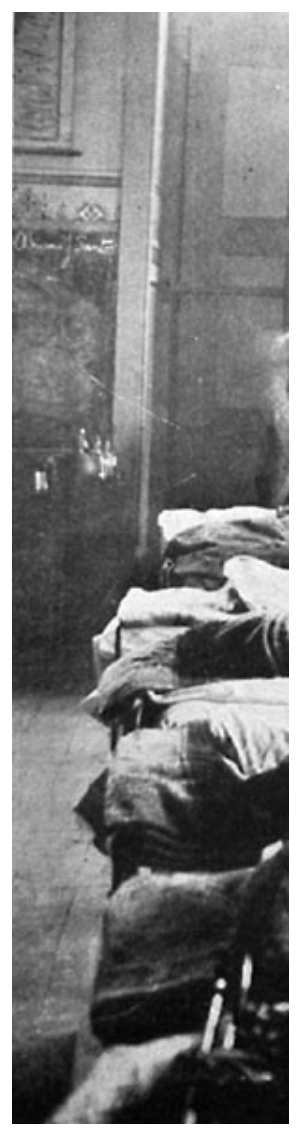



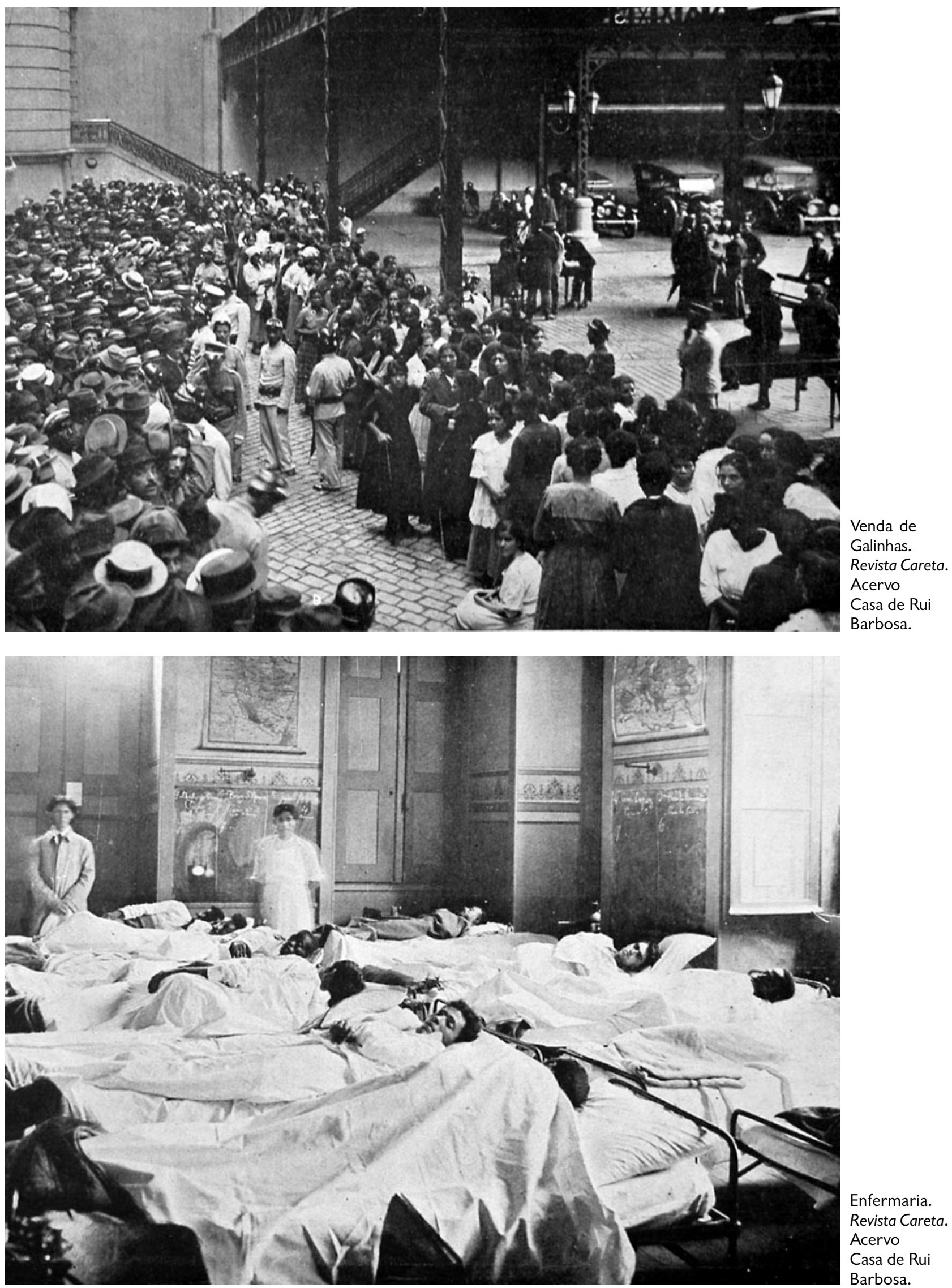

Enfermaria.

Revista Careta.

Acervo

Casa de Rui

Barbosa. 

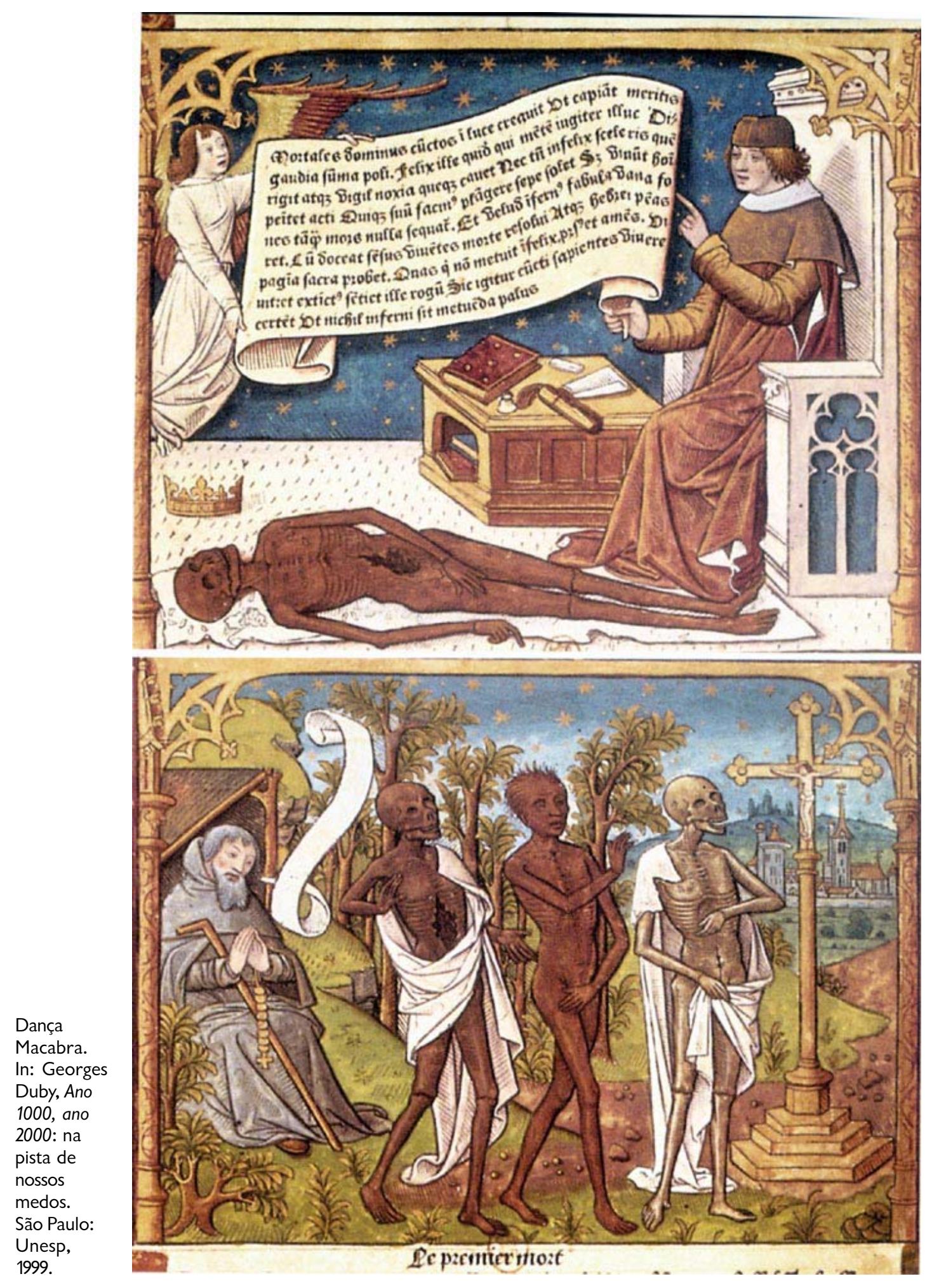


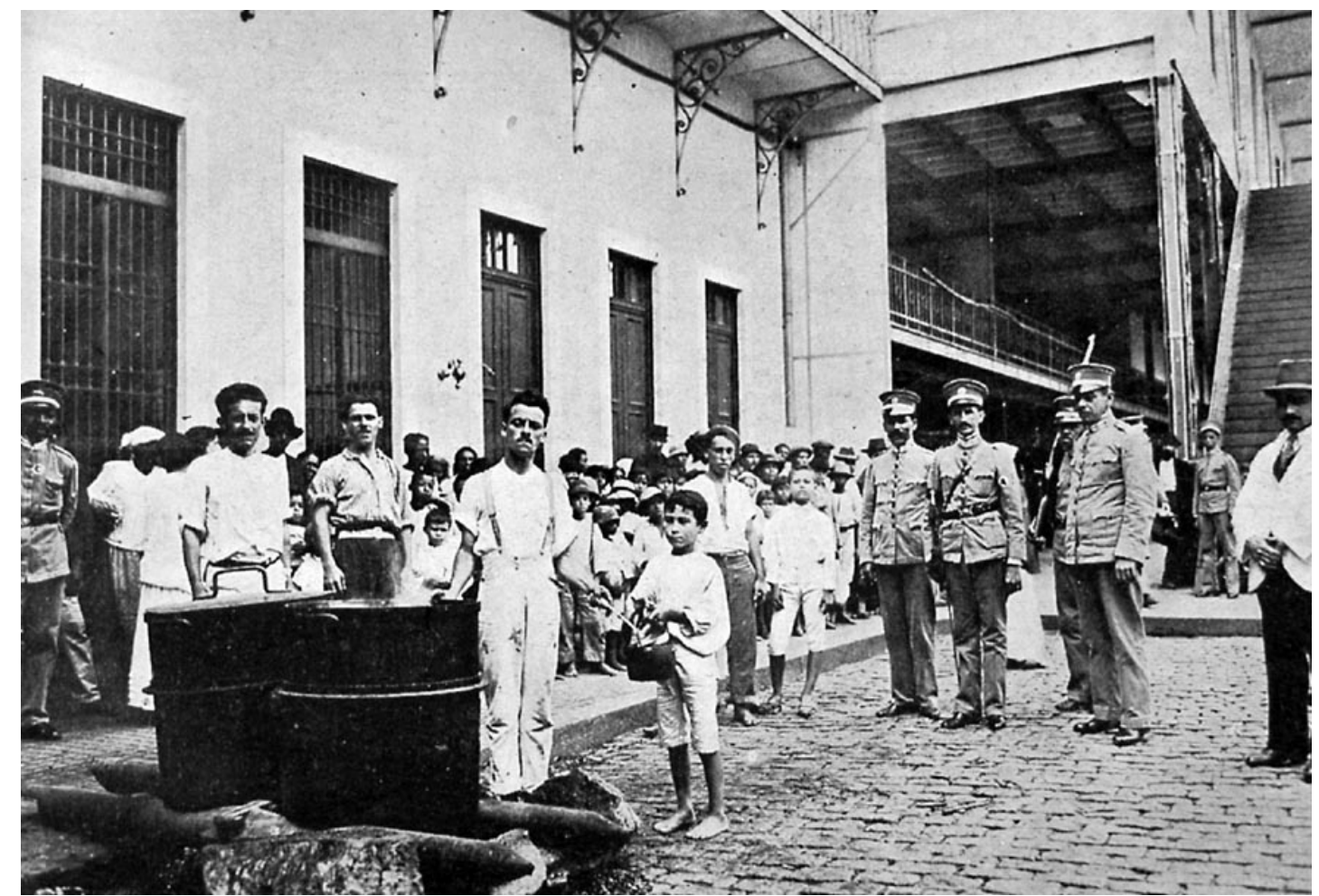

Distribuição de Caldo. Revista Careta. Acervo Casa de Rui Barbosa.

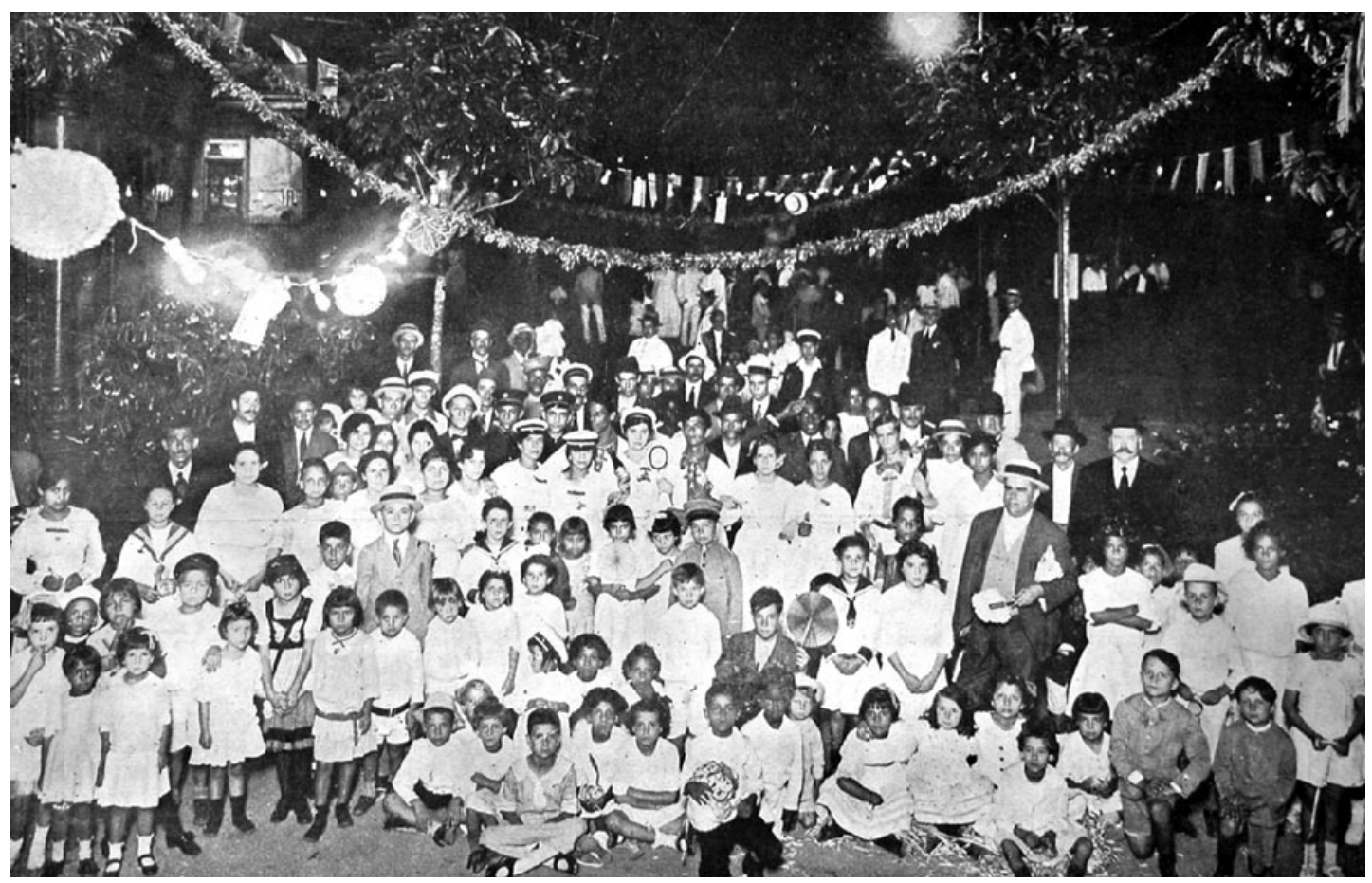

Batalha de confete. Revista Careta. Acervo Casa de Rui Barbosa. 


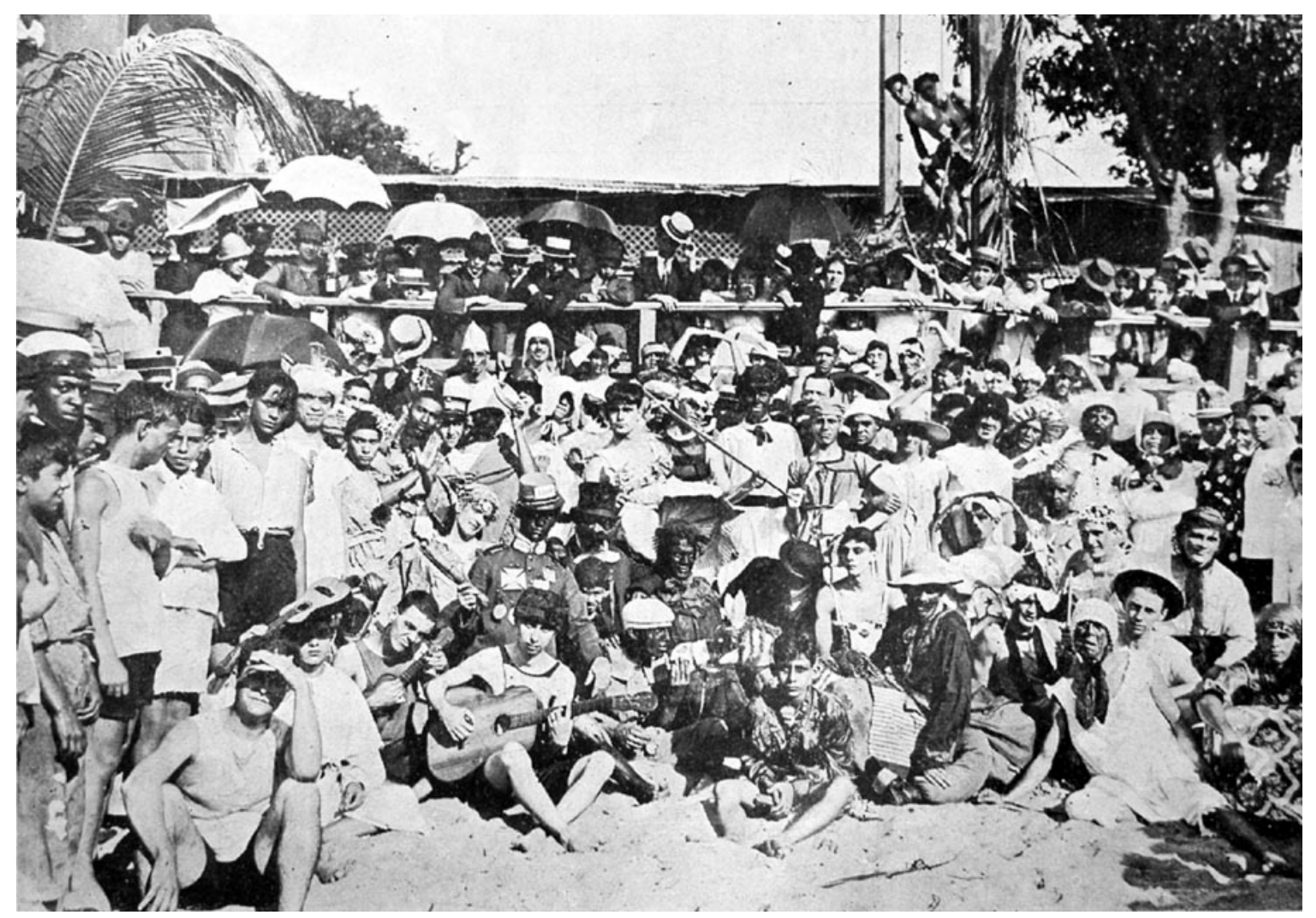

Banho de mar a fantasia. Revista Careta. Acervo Casa de Rui Barbosa.

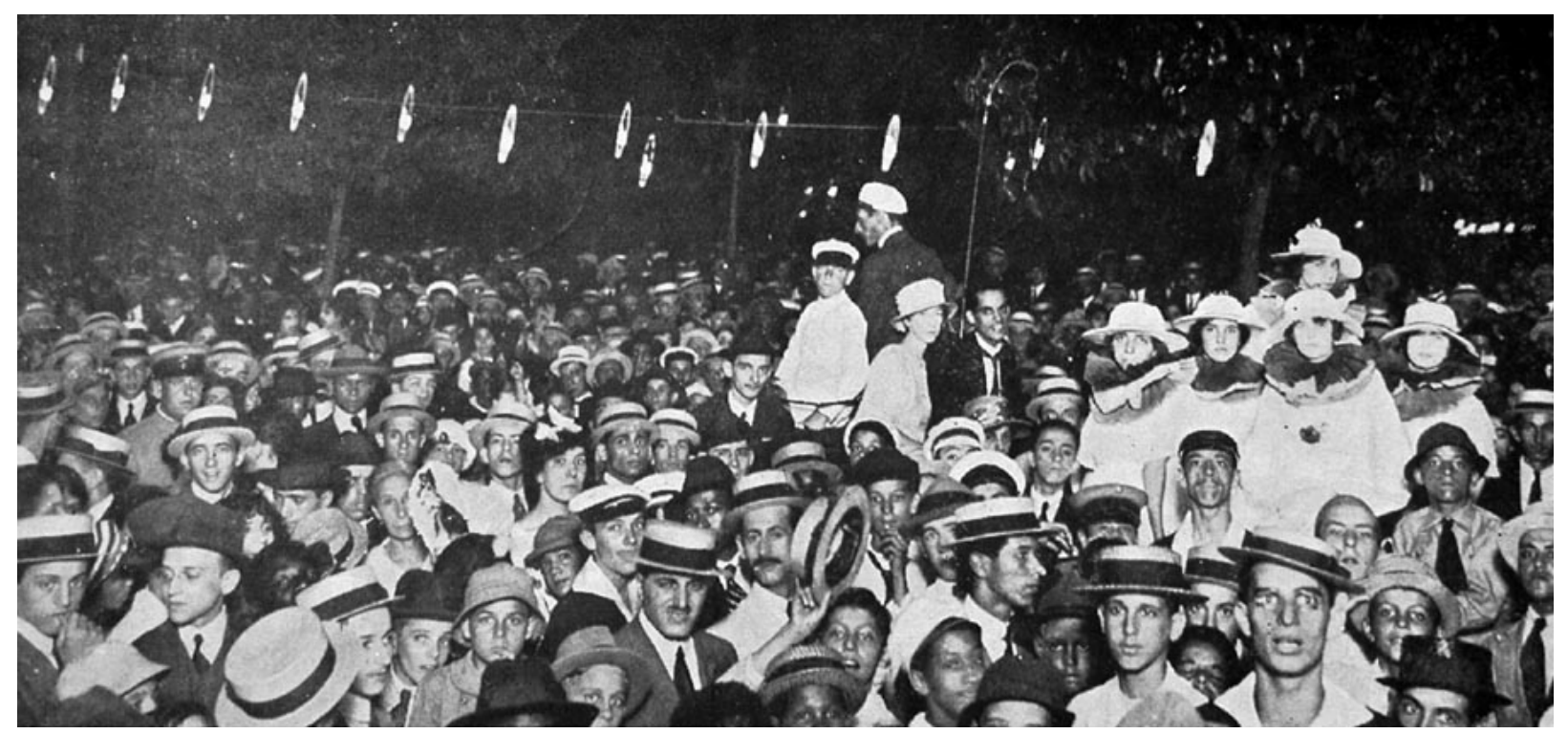

Batalha de confete. Revista Careta. Acervo Casa de Rui Barbosa. 


\section{NOTAS}

1 O correio da manhã, 11.01.1919.

2 Silva (2002).

3 Durante certo período de sua vida, Caninha ganhava a vida vendendo pedaços de cana-de-açúcar na estação de trens Central do Brasil, anunciando: "Olha a caninha, vamos comprar caninha doce!".

${ }^{4}$ Sobre a Festa da Penha e a importância das festas populares para a construção da identidade social da cidade do Rio de Janeiro, consultar Soihet, Rachel. "Festa da Penha: resistência e interpenetração cultural (1890-1920)", em Cunha (2002).

5 A epidemia começou no Rio de Janeiro em setembro de 1918 e permaneceu atingindo seus habitantes até novembro, ameaçando com surtos menos intensos durante o ano de 1919.

6 Sobre História das Doenças, consultar Nascimento (2005).

7 Rosenberg (1992) destaca as características invariáveis das epidemias: a negação, entre outras.

${ }^{8}$ Após o século XIX, passou a existir nas populações ocidentais a associação entre higiene corporal e saúde. Ver Corbin (1987) e Rodrigues (1995).

9 O livro é uma coletânea de narrativas sobre os acontecimentos vividos pelas pessoas que, fugindo da Peste, isolam-se numa atmosfera de sexo e divertimentos.

10 Albert Camus (1913-1960) escreveu o romance A peste, narrando acontecimentos relativos a uma epidemia na Argélia.

11 Existe um fato relativamente recente sobre a presença da punição divina no Rio de Janeiro. O santo padroeiro da cidade é São Sebastião, protetor das "pestes, doenças e epidemias". A memória coletiva popular guarda que em resposta à mudança do dia 20 de janeiro de feriado para dia útil, São Sebastião enviou as chuvas que causaram terrível destruição à cidade em meados da década de 1960.

12 "As danças macabras punham em cena o invencível esqueleto que arrastava à força para sua ronda fúnebre pessoas de qualquer idade e de qualquer condição" (Delumeau, 1990, p. 85).

13 Consultar Castro-Santos (1994).

14 Ver McNeill (1976) e Castro-Santos (1994).

15 Roupa usada por médicos no século XVII. Era composta de um tecido longo e espesso e botas de couro de cano alto. A cabeça era protegida por um capuz, com olhos de cristal e um longo bico, preenchido com perfumes e ervas. Carregavam um bastão.

16 "declaravam que, para tão imenso mal, eram remédios eficazes o beber abundantemente, o gozar com intensidade, o ir cantando de uma parte a outra, o divertir-se de todas as maneiras..." (Boccaccio, 1979, p. 13).

17 A característica rápida e crescente da enfermidade foi ressaltada e até mesmo exagerada. A figura do esqueleto vestido de trajes negros e armado de foice reforça este aspecto: a rapidez da morte.

18 A peste, como a varíola, a febre amarela, a cólera e a gripe, é uma das moléstias que violentamente marcaram a história das formações sociais, causando medo e mortes nas regiões onde aconteceram seus surtos. Memórias sobre epidemias na Antigüidade nos levam a crer que algumas dessas enfermidades estavam disseminadas na época.

19 Somente no final do século XIX, período em que progressiva e lentamente abandonou-se a teoria do contágio miasmático pelo paradigma da bacteriologia, os cientistas isolaram os mecanismos de propagação da Peste. Ver Rosen (1994).

20 Em Londres, segundo as fontes, morreram cerca de 60 mil pessoas durante a epidemia de 1665.

21 Em seu livro sobre a presença da melancolia na cultura ocidental, Moacir Scliar destaca a liberalização dos costumes após a peste: "As pessoas agora queriam comer bem, vestir-se bem, desfrutar de todos os prazeres possíveis - inclusive dos prazeres sexuais" (Scliar, 2003, p. 29).

22 A própria doença seria uma personagem dos becos medievais. Com seus caminhos povoados de homens e os mais diversos tipos de animais, "A cidade era espaço nada exclusivo de homens: cães, cordeiros, cabras, vacas, cavalos, porcos eram simultaneamente companhias, produtores e eliminadores de resíduos. Com os homens, em ruas e casas, conviviam os ratos..." (Rodrigues, 1999, p. 102).

23 Segundo Teixeira (1993) esse fato também aconteceu na epidemia de Gripe Espanhola em São Paulo, com os paulistanos procurando refúgios em cidades como Campos do Jordão. 
24 Cf. Ariès (1989), Duby (1999), Farrel (2003), Rocha \& Rocha (1986), Ruffie \& Sournia (1986) e Ujvari (2003).

25 Este dado se repete nas epidemias: a visão de que as doenças atacam a todos sem distinção de classes. Porém, isto vem sendo criticado. Segundo um bom número de pesquisas, é freqüentemente um equívoco.

26 Goulart (2003, p. 50) cita o depoimento de Nelson Antonio Freire, à época da gripe um jovem de 18 anos: "Houve um período em que o governo proibiu que se acompanhassem os enterros e o povo não gostou nadinha de não poder levar seus entes queridos à última morada".

27 Rodrigues (1997) demonstra como as atitudes perante a morte e os ritos fúnebres sofreram modificações a partir da epidemia de Febre Amarela de 1849-1850.

${ }^{28}$ Nas populações européias acometidas pela peste, acreditava-se no poder de salvação de São Sebastião. Como esse santo havia resistido à morte pelas flechas lançadas contra seu corpo, as pessoas o julgavam capaz de afastar as "lanças da peste bubônica" enviadas por seres divinos irados frente aos pecados cometidos pelos homens.

${ }^{29}$ Nelson Antonio Freire citado em Goulart (2003, p. 51): “Lembro-me bem quando minha mãezinha foi obrigada a jogar no meio da rua os corpos de meu tio, seu irmão mais novo que ela criara com tanta dedicação e amor, e de meu irmão mais velho. Depois disso ela nunca mais foi a mesma. Ficou tomada de uma melancolia".

30 Após a epidemia de Gripe Espanhola (1918), cresceram as críticas ao modelo de organização sanitária do país. Sobre a gripe e a criação em 1920 do Departamento Nacional de Saúde Pública, consultar Goulart (2003).

31 Sobre outro fato referente a uma punição divina, Sidney Chalhoub (1996, p. 195) registra que a Epidemia de Febre Amarela de 1849-1850 teria sido obra de São Benedito ofendido. Afastado de uma procissão, o andor do Santo não ocupou seu lugar. No verão seguinte, uma grande epidemia de Febre Amarela chegou ao Rio de Janeiro. Adeptos de São Benedito espalhavam que o flagelo era a vingança.

32 Segundo Nilson Rosário Costa, citado em Teixeira (1993), as áreas mais atingidas pela gripe foram justamente os subúrbios.

${ }^{33}$ É evidente que, em carnavais anteriores e posteriores, os habitantes da cidade divertiam-se durante o período do reinado de Momo. No entanto, é necessário ressaltar que foi nesse Carnaval de 1919 que o Rio de Janeiro 'brincou' com um evento que ainda estava causando reflexos terríveis. Sobre Carnaval e a identidade coletiva da cidade, consultar Lopes (2000).

34 Nicolau Sevcenko (1992) relata a mesma euforia em São Paulo no alvorecer de 1919, demonstrando que na paulicéia os habitantes haviam saído de um momento profundamente marcado por guerra, gripe e geadas.

35 Ver Azevedo, Nara. "La dansarina: a Gripe Espanhola e a vida cotidiana na cidade do Rio de Janeiro (1918)". História, Ciências, Saúde - Manguinhos, Rio de Janeiro, v. 4, n. 1, 1997, p.11-30.

36 Segundo Carlos Heitor Cony (2001), baseando-se em memórias de Mário Filho (1908-1966), “a esbórnia foi total!". Mario Lago (1911-2002) também registra a animação que tomou conta da cidade durante o período. Na mesma época a cidade comemorou o fim da guerra. Ver Velloso (1997).

37 Sobre as relações entre sociedade, Estado e a moral sexual das camadas populares nessa conjuntura existem dois excelentes trabalhos: o de Marta de Abreu Esteves (1989) e o de Sueann Caulfield (2000).

38 Semelhante ao ocorrido com as epidemias de peste ou mesmo de outras doenças contagiosas.

39 “E o homem da carroça não tinha melindres, nem pudores. Levava doentes ainda estrebuchando. No cemitério, tudo era possível. Os coveiros acabavam de matar a pau, a picareta, os agonizantes. Nada de túmulos exclusivos. Todo mundo era despejado em buracos, crateras hediondas. Por vezes, a vala era tão superficial que, de repente, um pé florescia na terra..." (Rodrigues, 1967, p. 73).

40 Caulfied (2000) afirma com base nos documentos existentes no acervo do Arquivo Nacional que, entre 1920 e 1940, os inquéritos de defloramentos na cidade do Rio de Janeiro somavam cerca de quinhentos por ano. Número bastante superior aos outros crimes durante o mesmo período.

41 Em relação ao Carnaval de 1919, várias perguntas ainda estão por serem respondidas. Como as diferentes classes sociais 'brincaram' o carnaval da gripe? Neste texto, optamos por trabalhar um pequeno número das possibilidades de pesquisa que o tema apresenta. Um assunto pouco explorado é a criação do "Comitê PróCombate à Epidemia", criado por associações operárias, durante a Gripe Espanhola. Um dos raros trabalhos acadêmicos que estuda a Insurreição Anarquista de novembro de 1918 é o de Carlos Augusto Addor (1986). 


\section{REFERÊNCIAS BIBLIOGRÁFICAS}

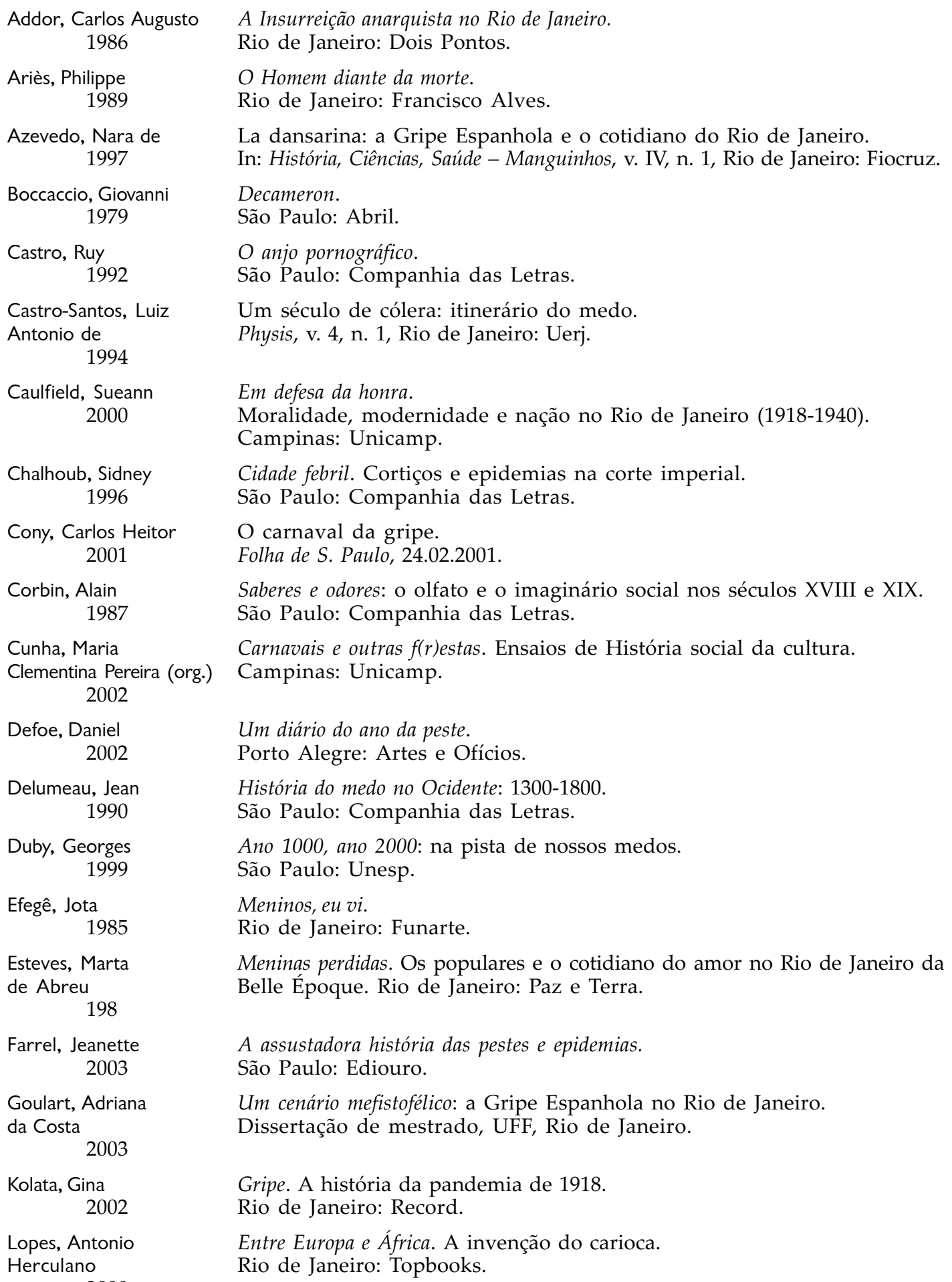




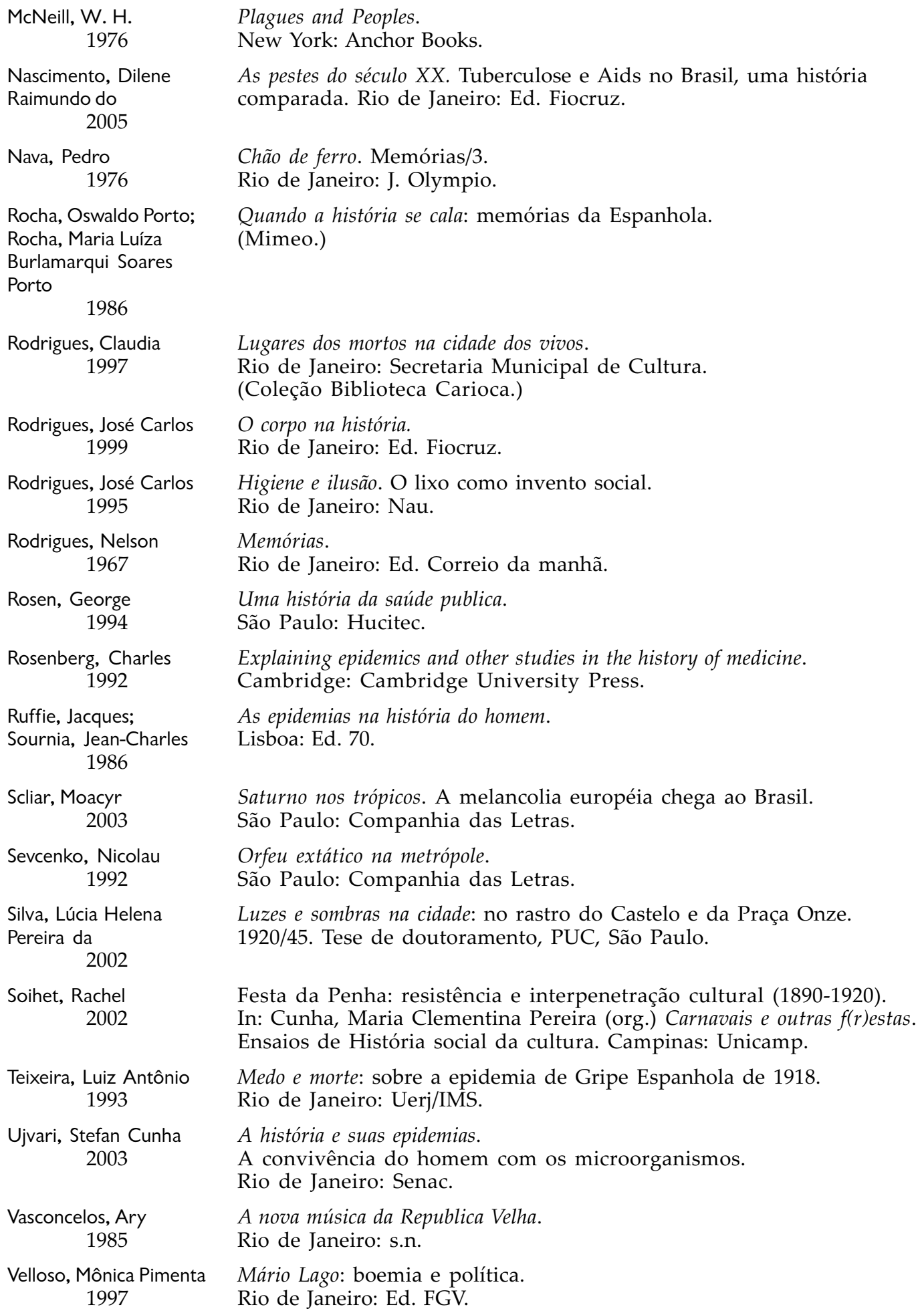

Lugares dos mortos na cidade dos vivos.

Rio de Janeiro: Secretaria Municipal de Cultura.

(Coleção Biblioteca Carioca.)

O corpo na história.

Rio de Janeiro: Ed. Fiocruz.

Higiene e ilusão. O lixo como invento social.

Rio de Janeiro: Nau.

Memórias.

Rio de Janeiro: Ed. Correio da manhã.

Uma história da saúde publica.

São Paulo: Hucitec.

Explaining epidemics and other studies in the history of medicine. Cambridge: Cambridge University Press.

As epidemias na história do homem.

Lisboa: Ed. 70.

Saturno nos trópicos. A melancolia européia chega ao Brasil. São Paulo: Companhia das Letras.

Orfeu extático na metrópole.

São Paulo: Companhia das Letras.

Luzes e sombras na cidade: no rastro do Castelo e da Praça Onze.

1920/45. Tese de doutoramento, PUC, São Paulo.

Festa da Penha: resistência e interpenetração cultural (1890-1920).

In: Cunha, Maria Clementina Pereira (org.) Carnavais e outras $f(r)$ estas. Ensaios de História social da cultura. Campinas: Unicamp.

Medo e morte: sobre a epidemia de Gripe Espanhola de 1918.

Rio de Janeiro: Uerj/IMS.

A história e suas epidemias.

A convivência do homem com os microorganismos.

Rio de Janeiro: Senac.

A nova música da Republica Velha.

Rio de Janeiro: s.n.

Mário Lago: boemia e política.

Rio de Janeiro: Ed. FGV.

Recebido para publicação em março de 2005.

Aprovado para publicação em setembro de 2005. 